\title{
Official Financial Flows, Capital Mobility, and Global Imbalances
}




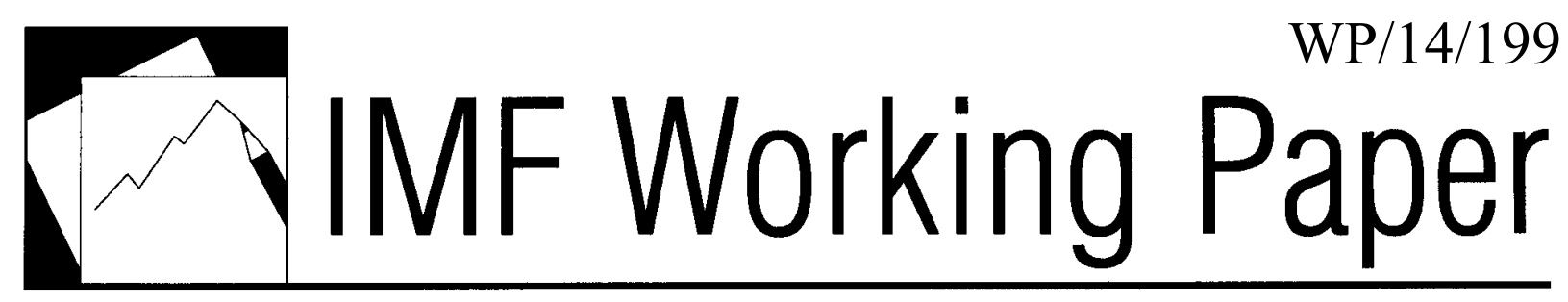

\section{Official Financial Flows, Capital Mobility, and Global Imbalances}

Tamim Bayoumi, Joseph Gagnon, and Christian Saborowski 


\title{
IMF Working Paper
}

Strategy, Policy, and Review Department

\section{Official Financial Flows, Capital Mobility, and Global Imbalances}

\section{Prepared by Tamim Bayoumi, Joseph Gagnon, and Christian Saborowski}

Authorized for distribution by Tamim Bayoumi

October 2014

\section{This Working Paper should not be reported as representing the views of the IMF.}

The views expressed in this Working Paper are those of the author(s) and do not necessarily represent those of the IMF or IMF policy. Working Papers describe research in progress by the author(s) and are published to elicit comments and to further debate.

\begin{abstract}
We use a cross-country panel framework to analyze the effect of net official flows (chiefly foreign exchange intervention) on current accounts. We find that net official flows have a large but plausible effect on current account balances. The estimated effects are larger with instrumental variables ( 42 cents to the dollar on average compared to 24 without instruments), reflecting a possible downward bias in regressions without instruments owing to an endogenous response of net official flows to private financial flows. We consistently find larger impacts of net official flows when international capital flows are restricted and smaller impacts when capital is highly mobile. A further result is that there is an important positive effect of lagged net official flows on current accounts that we believe operates through the portfolio balance channel.
\end{abstract}

JEL Classification Numbers: E5, F3

Keywords: reserve accumulation, intervention, capital mobility

Author’s E-Mail Address: tbayoumi@imf.org, igagnon@piie.com, csaborowski@imf.org; 


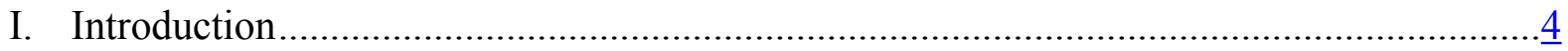

II. Background and Motivation ................................................................................

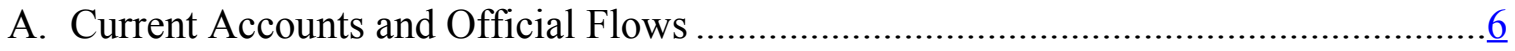

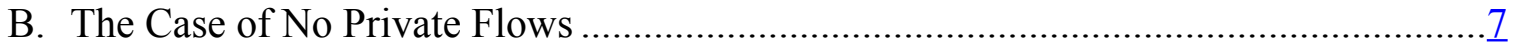

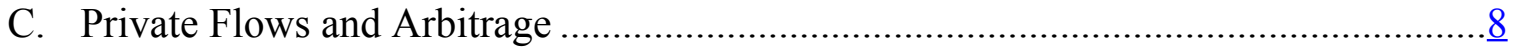

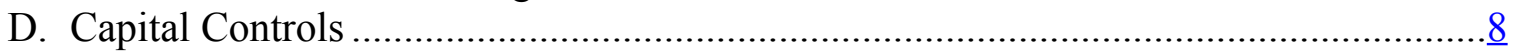

E. Institutional Quality ......................................................................................

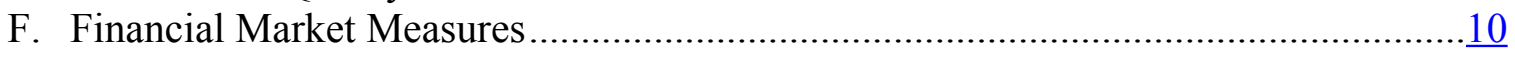

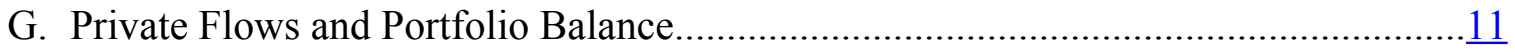

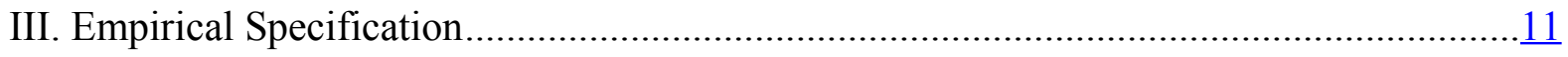

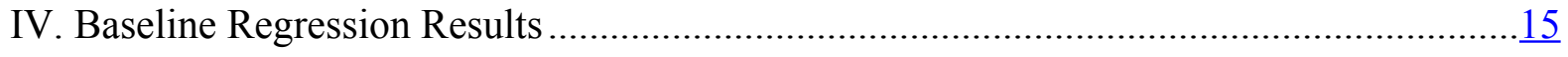

V. Robustness to Sample and Specification .......................................................... 19

VI. Comparison to Previous Studies ...............................................................................

VII. Illustration of Fitted Model for Individual Countries..............................................24

VIII. Conclusion ............................................................................................... 25

Box

1. Investment as Pure Diversification ......................................................................

Tables

1. Definition of Instruments .....................................................................................

2. Baseline Specification with Various Capital Mobility Measures and Preferred Set of

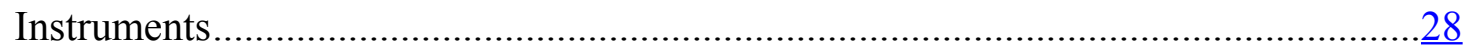

3. Regressions Including Various Mobility Measures without Instruments.......................... $\underline{30}$

4. Regressions Including Various Mobility Measures with Alternative Set of Instruments .... $\underline{32}$

5. Robustness Checks With Quinn Measure of Capital Mobility ........................................

6. Robustness Checks with BOP Financial Ratio to GDP Measure of Capital Mobility ......... $\underline{35}$

7. Robustness Checks with PC Alt Measure of Capital Mobility.........................................

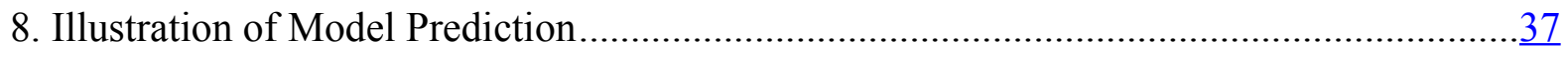

Figures

1. Net Official Financial Flows..................................................................................... $\underline{38}$

2. Net External Accounts of Countries with Current Account Surpluses.............................. $\underline{38}$

3. Median Values of Capital Controls.......................................................................... $\underline{39}$

4. Median Values of Institutional Quality Measures ....................................................... 39

5. Median Values of Financial Market Measures .......................................................... 40

6. Coefficients on Net Official Flows Term under Low and High Mobility ......................... $\underline{40}$

Appendix

Data Sources and Definitions...............................................................................

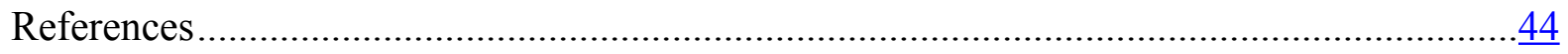




\section{INTRODUCTION ${ }^{1}$}

Government-directed, or official, financial flows (dominated by purchases of foreign exchange reserves) have exploded over the past 15 years and are now running at more than $\$ 1$ trillion per year. Current account imbalances also reached record levels in recent years and they remain a major source of tension in international economic policy, despite a partial retrenchment since 2007. Advanced economies see emerging ones as frustrating needed current account adjustment via reserve accumulation aimed at holding down the values of their currencies. Emerging economies see their advanced brethren as trying to export their way out of recession via loose monetary policies that tend to weaken their currencies. Hence the much publicized talk of currency wars.

This paper explores the first of these two arguments: Are official flows frustrating current account adjustment? Of particular interest is the extent to which official flows have a greater impact on current accounts in the presence of capital controls or other barriers to capital mobility. In addition, we explore whether there is a longer lasting impact of official flows on current accounts through the portfolio balance channel.

The paper follows in the footsteps of Chinn and Prasad (2003), Chinn and Ito (2008), Lee et al. (2008), and others who use a cross-country time-series approach to estimate the underlying determinants of current accounts. Bayoumi and Saborowski (2014), Gagnon (2012, 2013), and IMF (2012, 2013) augment the Chinn and Prasad framework to include reserve accumulation or net official financial flows as a measure of a government's exchange rate policy. ${ }^{2}$ All five studies find a significant effect of net official flows on the current account balance. However, Bayoumi and Saborowski and IMF find that the effect of official flows is significant only in countries with capital controls, whereas Gagnon finds a large effect of official flows that is not sensitive to measures of capital controls. ${ }^{3}$ Understanding the differences in data and specification that give rise to these conflicting results is a key objective of this paper.

We use a cross-country panel approach to analyze the effect of net official flows on current accounts. The sample runs up to 26 years, from 1986 through 2011 although the baseline sample is de-facto restricted to the period of 1995-2010. A key empirical issue is the potential endogeneity of official flows to shocks to current account balances and net private flows. Endogenous movements

\footnotetext{
${ }^{1}$ We thank Kent Troutman for expert research assistance. We also thank Gustavo Adler, Joshua Aizenman, Marcos Chamon, Menzie Chinn, Robert Dekle, Bradley Jones, Zheng Liu, Gian Maria Milesi-Ferretti, Steve Phillips, Helene Poirson Ward, Saadi Sedik and participants at the 2014 Royal Economic Society conference in Manchester and the 2014 Journal of International Money and Finance-University of Southern California conference in Los Angeles for helpful comments and suggestions. Any remaining errors are our own.

${ }^{2}$ Reinhart, Ricci, and Tressel (2010) find that reserve accumulation is positively associated with the current account, mainly for countries with capital controls. Aizenman, Jinjarak, and Marion (2013) also find a positive connection between reserve accumulation and current accounts.

${ }^{3}$ All these studies tested for the role of capital controls by creating an interaction term that is the product of net official flows and a measure of legal restrictions on financial flows. The legal measures are displayed in Figure 3.
} 
are most likely to arise from attempts to stabilize the exchange rate in the face of trade or financial market shocks. The model is thus estimated via two-stage least squares. We propose a set of instruments for net official flows chosen to reflect possible exogenous reasons why policymakers may choose to accumulate official assets including for precautionary reasons, to save resource revenues for future generations, to borrow for economic development, or to achieve economic growth through higher net exports.

We find that net official flows have a large but plausible effect on current account balances. This result is robust to an array of samples, specifications, and estimation techniques. The estimated effects are larger with instrumental variables (42 cents to the dollar on average compared to 24 without instruments), reflecting possible downward bias in regressions without instruments owing to an endogenous response of net official flows to private financial flows.

We also find that the impact of net official flows is importantly affected by the extent of international capital mobility. We explore various measures of capital mobility. Nearly all of these measures show that the effect of net official flows on the current account declines as mobility increases. In our baseline specification, across all our measures of capital mobility, current accounts increase on average by 18 cents for each dollar of intervention in countries with capital mobility above the median compared to 66 cents to the dollar in countries with low mobility.

These results are robust to varying samples and specifications. However, coefficient magnitudes for lower capital mobility are sensitive to the countries and years included in the analysis. While our preferred specification predicts an average effect of 42 cents to the dollar, our robustness checks illustrate that the confidence interval around this number remains rather wide.

A further result is that there is an important effect of lagged net official flows, captured by the coefficient on the lagged stock of net official assets. We believe this effect operates through the portfolio balance channel. Persistent changes in the relative supplies of assets in different currencies have persistent effects on exchange rates and current account balances. This effect often, but not always, appears to increase with capital mobility, probably indicating that the portfolio channel is less important when private flows are tightly restricted. There is also some tradeoff across samples and specifications in the estimates of the net official flow and net official stock effects. When flow effects are estimated to be larger, stock effects typically are estimated to be smaller.

The paper is organized as follows: Section 2 presents the theoretical arguments underlying the hypotheses tested in this paper and discusses various measures of capital mobility. Section 3 illustrates our empirical specification and motivates the use of instrumental variables while Section 4 analyzes the regression results under the baseline specification. Section 5 presents robustness checks to the baseline regressions. Section 6 compares our results to previous research, and Section 7 illustrates the fitted model for individual countries. Section 8 concludes. 


\section{BACKGROUND AND MOTIVATION}

\section{A. Current Accounts and Official Flows}

We define official financial flows as the acquisition and disposition of assets and liabilities denominated in foreign currencies by public-sector institutions in the reporting country. ${ }^{4}$ The dominant form of official flows is purchases of foreign exchange reserves. However, public-sector borrowing in foreign currency counts as a negative official flow. Foreign asset purchases by sovereign wealth funds (SWFs) also count as official financial flows. ${ }^{5}$ We exclude countries with significant SWFs for which data do not allow the construction of comprehensive official flows.

Note that purchases and sales of a country's assets by official institutions in other countries are not classified as official flows of the country in question. For example, purchases of US assets by Norway's SWF count as official outflows for Norway but private inflows for the United States. Gagnon (2013) and Bayoumi and Saborowski (2014) used IMF data on the currency composition of official foreign exchange reserves (COFER) to estimate data on foreign official flows but found that these data had little effect on the coefficient of interest. ${ }^{6}$ To some extent, the use of time effects in our regressions controls for the spillover of net official flows onto other countries' current account balances, although this would implicitly assume the spillover is equal across all countries.

According to the balance of payments (BOP) accounts, in the absence of statistical errors and omissions, a country's current account must equal its financial account. ${ }^{7}$ A current account surplus implies net lending abroad (positive financial flows) whereas a current account deficit implies net borrowing from abroad (negative financial flows). The financial account, in turn, is the sum of net official financial flows and net private financial flows. These relationships are defined in equation 1 .

$$
\text { Current Account }=\text { Net Official Flows }+ \text { Net Private Flows }
$$

\footnotetext{
${ }^{4}$ We assume that monetary policy fully offsets, or "sterilizes," any potential inflationary effects of accumulation of foreign assets, whether by the monetary authority or by other public institutions. We conduct some tests that support this assumption.

${ }^{5}$ Although SWF data are not included in standard databases for some countries, we construct official flows and stocks for a limited number of countries using various sources of data as detailed in the Appendix to this paper.

${ }^{6}$ Gagnon ran alternative regressions in which net official flows were defined to include flows by both domestic and foreign official institutions. He found a better fit for the United States but a worse fit for other reserve-issuing countries and little change in the overall fit of the regression or the coefficients. Bayoumi and Saborowski tested various hypotheses as to how capital outflows resulting from official outflows may be distributed across countries. They find that the main offset to global official capital outflows can be found in the current account of the United States, with some evidence for flows ending up in large and open emerging markets.

${ }^{7}$ There are also some transfers of assets and forgiveness of loans that are not included in the financial account, but these are tiny for most countries.
} 
As shown in Figure 1, net official flows grew rapidly in the years before the global financial crisis and have fluctuated around $\$ 1$ trillion per year since then. The solid line in Figure 2 displays the sum of all the positive current account balances in each year (in percent of world GDP), which is a measure of global current account imbalances. ${ }^{8}$ The figure shows that these imbalances reached record levels late last decade.

The dashed line in Figure 2 is net official flows, and the dotted line is net private flows, for the same countries whose combined current account surplus is displayed in the solid line. Thus, the dashed and dotted lines sum up to the solid line, except for a relatively small statistical error. The rise in current account imbalances since 2000 is clearly associated with an increase in net official flows of a strikingly similar magnitude, whereas net private flows declined slightly and appear unrelated to the combined current account surplus.

The focus of this paper is on establishing whether this close correlation reflects a causal relationship running from official flows to current accounts, although causality need not run in only one direction. There are two ways in which purchases of official reserves could drive the current account. The first is through their impact on monetary policy and interest rates and hence domestic demand and activity; this is unsterilized intervention. The second is the impact of reserve accumulation on the exchange rate and the current account even when intervention is sterilized. In this paper, we focus on the latter effect.

\section{B. The Case of No Private Flows}

In the absence of private financial flows, Equation 1 implies that a country's current account balance must equal its net official financial flows. In this case, an increase in net official flows increases the current account via depreciation of the exchange rate regardless of whether the official flow is fully sterilized or not. A net official financial outflow implies a transfer of capital from the home country to the rest of the world. The reduction in the domestic capital stock raises the marginal product of capital at home and the increase in the foreign capital stock lowers the marginal product abroad. This bids up domestic rates of return and pushes down foreign rates of return. ${ }^{9}$ In a world without private financial flows, interest rates and other rates of return on financial assets and the underlying capital stock can remain different across countries for extended periods of time.

\footnotetext{
${ }^{8}$ The countries included in this sum vary from year to year according to whether their current accounts moved between deficits and surpluses.

${ }^{9}$ The effect on domestic rates of return happens immediately in the case of sterilized intervention, but it may be delayed in the case of unsterilized intervention until inflation stabilizes. We are concerned with real, or inflation-adjusted, rates of return.
} 


\section{Private Flows and Arbitrage}

When private investors are allowed to send capital across borders, they will tend to arbitrage these different rates of return. Starting from a position of equal rates of return across countries, a net outflow of official capital that is fully sterilized creates an arbitrage opportunity through incipient differences in rates of return. ${ }^{10}$ Private investors will take advantage of this opportunity and send capital in the opposite direction, from the rest of the world to the home country. Thus, positive net official flows will give rise to negative net private financial flows. The standard benchmark with fully open private financial markets is uncovered interest rate parity (UIRP), according to which private financial flows keep expected exchange-rate-adjusted rates of return equal across countries. Under UIRP, sterilized official flows have no effect on the current account because they are fully offset by private financial flows.

So far, we have shown that there is a one-to-one relationship between net official flows and the current account when private financial markets are closed. And, in the opposite extreme of efficient financial markets with perfect capital mobility, sterilized official flows have no effect on the current account because they are fully offset by private flows. ${ }^{11}$ Next, we consider intermediate cases in which capital mobility is imperfect, implying that the UIRP relationship breaks down, allowing official flows to have an effect on current accounts.

\section{Capital Controls}

Capital controls are one potential source of imperfect capital mobility. However, the implications for the link between official flows and the current account depend on the nature of the capital control. We consider two broad types of controls: taxes and quantity controls.

- $\quad$ An across-the-board withholding tax on interest, dividends, and profits earned by foreigners creates a fixed wedge between domestic and foreign rates of return. If the withholding tax rate stays constant, and UIRP would otherwise hold, then official flows have no effect on the current account because private flows adjust to maintain the fixed differential in the rates of return.

- Quantity controls place limits on the volume of private financial flows. ${ }^{12}$ Binding quotas on inward and outward private financial flows imply that, ceteris paribus, a change in net official flows must be exactly matched by a change in the current account. In the

\footnotetext{
${ }^{10}$ As in the case above, these effects are delayed when intervention is not sterilized.

${ }^{11}$ Even with fully efficient markets, sterilized official flows may have an effect if they are viewed as signals about future monetary policy. For example, a purchase of foreign assets may signal a future easing of monetary policy. However, if policy is not eased, the effect will be short-lived, and if policy is eased it will be similar to unsterilized intervention.

${ }^{12}$ For example, China limits the value of domestic equity that can be held by foreigners through its qualified foreign institutional investor scheme and forbids most forms of foreign investment in domestically issued debt instruments. It also imposes quotas on various classes of outward investment.
} 
extreme, as quotas approach zero, private cross-border financial flows are eliminated.

If financial markets are segmented, so that arbitrage is limited between foreign direct investment, portfolio equity, portfolio debt, bank debt, and other forms of capital, then it is possible that net official flows can have an effect between zero and one when quotas bind on some but not all financial instruments. As quotas become binding on more financial instruments, the effect of official flows on the current account should increase.

Menzie Chinn and Hiro Ito (2006), Dennis Quinn (1997), and Martin Schindler (2009) created indexes of the number of legal constraints on capital flows across different forms of capital for many countries and years. The Schindler index only spans the period 1995-2005. In order to allow using more recent data, this paper employs a variation of the Schindler index that employs some limited judgment, namely the Fund staff's narrow de jure restrictiveness index (Fund index). ${ }^{13}$ Figure 3 plots median values of these measures in each year, where measures are normalized to be bounded between zero and one with higher values denoting fewer controls. Two of these measures show a trend increase in financial openness, which should imply a declining effect of net official flows on the current account for the median country. Notably, the Quinn measure finds that more than half of all countries had removed all quantitative controls on financial flows by 2009 , yielding the highest possible median value of 1 . The Chinn-Ito measure displays substantial liberalization over time, but significant controls remained as of 2011. The Fund measure starts in 1995 and shows little trend between 1995 and 2011 for the median country.

\section{E. Institutional Quality}

There are strong reasons to believe that legal controls on financial flows are not the only factor influencing the mobility of capital. Private investors may not send capital freely into countries with few or no controls if they have reason to doubt the safety of their investments. Potential concerns include the quality of financial supervision and regulation, the ability to obtain redress of fraud and negligence in the court system, the stability of the economic environment, and the risk of expropriation or discriminatory treatment by host governments.

The World Bank's Worldwide Governance Indicators (WGI) are a widely used source of indicators of institutional quality. ${ }^{14}$ The PRS Group's International Country Risk Guide (ICRG) provides measures of political, economic and financial risk by country. ${ }^{15}$ We experimented with

\footnotetext{
${ }^{13}$ The index was used in the studies underpinning the IMF's new institutional view on capital controls: http://www.imf.org/external/pubs/ft/survey/so/2012/POL120312A.htm.

${ }^{14}$ The WGI indicators include voice and accountability, political stability and absence of violence, government effectiveness, regulatory quality, rule of law, and control of corruption.

${ }^{15}$ The ICRG comprises measures of political risk, economic risk, and financial risk as well as a composite indicator.
} 
the full set of measures and many of them are highly correlated. The paper focuses on three: the WGI rule of law and regulatory quality indexes and the ICRG composite risk index.

Figure 4 displays the median values of these three indicators. The median financial risk index (the dotted line) increased sharply after 1990, representing a marked decline in perceived financial risks at that time. There is little trend in this measure since the early 1990s. The solid line shows that the median value of the regulatory quality index has increased somewhat since its inception in 1995, but this increase is small relative to the overall scale of the index (0-100). The rule of law index (the dashed line) has declined somewhat over time, but this change is also small relative to the scale of the index.

\section{F. Financial Market Measures}

Financial market outcomes provide alternative proxies for capital mobility. We use size indicators, both of cross-border financial transactions and of the domestic financial system. Intuitively, the magnitude of cross-border financial flows may be seen as the direct outcome of capital mobility. Alternatively, a country with a large domestic financial system may be viewed by investors as closely integrated into the global financial system. We consider three financial market measures: (1) the ratio of gross private financial transactions to the sum of gross current and gross private financial transactions in the BOP accounts; (2) the ratio of gross private financial transactions in the BOP accounts to nominal GDP; and (3) the ratio of total bank assets to GDP. ${ }^{16}{ }^{17}$ Box 1 presents a simple model of cross-border investment driven solely by diversification which implies that the effect of net official flows on the current account should be inversely related to the first of these measures.

The solid line in Figure 5 is the median value of the share of private financial transactions in total BOP transactions (excluding reserve accumulation). This measure has trended up over time, but it has given back some of its gains since 2007. The dashed line is the median value of private financial BOP transactions relative to GDP. The gains over time are even more pronounced for this measure, reflecting the growing size of cross-border transactions in the world economy. The dotted line is the median value of bank assets to GDP, which has also grown over time and has retrenched by less since its peak than the BOP-based measures.

\footnotetext{
${ }^{16}$ Gross transactions are defined as the major categories in the financial account (FDI assets and liabilities, PI assets and liabilities and $\mathrm{OI}$ assets and liabilities). In the case of private transactions, we subtract all official transactions from the total.

${ }^{17}$ Regressions are based on annual observations in these measures rather than averages over time.
} 
Box 1. Investment as Pure Diversification

The model is based on the idea that uncertainty about expected rates of return across countries is a potential impediment that could constrain private flows from offsetting the impact of official flows. In an extreme case, market participants may have no views on differences in expected returns across countries. Nevertheless, investors may wish to reduce the overall variance of their portfolio returns by diversifying across countries. Private financial flows will then occur purely to reap the benefits of diversification. Private investors at home (US) and in the rest of the world (ROW) send financial outflows that are fixed in terms of their respective domestic currencies. In addition, for simplicity, we assume that trade flows in the current account have unitary price elasticities of demand. This implies that imports into each country are constant in terms of local currency.

Let M be US imports, fixed in $\$$ terms; $X$ is US exports, fixed in $€$ terms; PFO is US outward private financial flow, fixed in \$ terms; PFI is US inward private financial flow, fixed in $€$ terms; NOF is US net official flow in \$ (ROW assumed to be 0); $\mathrm{E}$ is the exchange rate, in $\$ / €$. The BOP identity is $E * X-M=P F O-E * P F I+N O F$

The effect of NOF on the current account is: $\frac{\Delta(E * X-M)}{\Delta N O F}=\frac{E * X}{E *(X+P F I)}$

The effect of NOF on net private flows, in turn, is given by: $\frac{\Delta(P F O-E * P F I)}{\Delta N O F}=\frac{-E * P F I}{E *(X+P F I)}$

The exchange rate is determined statically based on trade flows and financial flows according to the BOP identity. An increase in net official flows pushes down the value of the domestic currency against the foreign currency, implying a rise in E. The effect on the current account is proportional to the ratio of exports to the sum of exports and private financial inflows. The effect on net private flows is -1 times the ratio of private financial inflows to the sum of exports and private financial inflows. An analogous ratio expresses the effect on ROW net private flows as the ratio of PFO to M+PFO. In order to generalize this effect from the point of view of all countries, we compute our measure of capital mobility as: Mobility $=\frac{P F O+E * P F I}{E * X+M+P F O+E * P F I}$

\section{G. Private Flows and Portfolio Balance}

In a world of risk-averse investors, UIRP need not hold even in the absence of legal controls and even with high-quality regulatory regimes. Volatile exchange rates are a particularly important source of risk. The portfolio balance theory holds that relative supplies of assets in different currencies will influence the exchange rates between these currencies through investors' desire to maintain a specific balance of portfolio holdings (Branson and Henderson 1985). An increase in domestic-currency assets will depreciate the domestic exchange rate, setting up expectations of higher future returns relative to returns on foreign currency and thus inducing investors to hold the additional supply. The link between capital mobility and the portfolio balance channel is ambiguous. One the one hand, a lack of mobility may prohibit investors from balancing their portfolios, on the other hand, portfolio rebalancing may be inherently more important when investors face tight exposure limits in countries that are less closely integrated into the global financial system

\section{EMPIRICAL SPECIFICATION}

The regressions are run on a sample period of up to 26 years, from 1986 through 2011. In principle, the maximum number of observations is 2054 . However, owing to limitations on data availability, the baseline regressions use only 794 observations for 72 countries (see list of countries in the Appendix) while robustness checks on larger samples use up to 1213 
observations. ${ }^{18}$ The coefficient standard errors in all regressions, including those using instruments, are robust to heteroskedastic and first-order autoregressive errors. Further information on the data is contained in the appendix. Equations 2 and 3 present the two basic specifications used in the analysis.

$$
\begin{aligned}
& \frac{\mathrm{CAX}_{\mathrm{it}}}{\mathrm{GDP}_{\mathrm{it}}}={ }_{1}\left(\mathrm{NOF}_{\mathrm{it}} / \mathrm{GDP}_{\mathrm{it}}\right)+{ }_{2}\left(\mathrm{NOF}_{\mathrm{it}} \mathrm{HIGHMOB}_{\mathrm{it}-1} / \mathrm{GDP}_{\mathrm{it}}\right)+{ }_{1}\left(\mathrm{NOA}_{\mathrm{it}-1} / \mathrm{GDP}_{\mathrm{it}-1}\right)+
\end{aligned}
$$

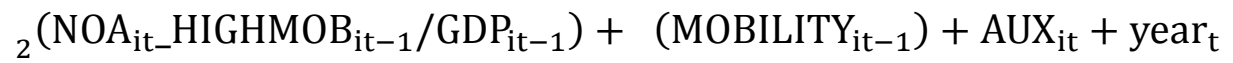

$$
\begin{aligned}
& \frac{\mathrm{NPFX}_{\mathrm{it}}}{\mathrm{GDP}_{\mathrm{it}}}=\left({ }_{1}-1\right)\left(\mathrm{NOF}_{\mathrm{it}} / \mathrm{GDP}_{\mathrm{it}}\right)+{ }_{2}\left(\mathrm{NOF}_{\mathrm{it}-} \mathrm{HIGHMOB}_{\mathrm{it}-1} / \mathrm{GDP}_{\mathrm{it}}\right)+{ }_{1}\left(\mathrm{NOA}_{\mathrm{it}-1} / \mathrm{GDP}_{\mathrm{it}-1}\right)+ \\
& { }_{2}\left(\mathrm{NOA}_{\mathrm{it}-} \mathrm{HIGHMOB}_{\mathrm{it}-1} / \mathrm{GDP}_{\mathrm{it}-1}\right)+\left(\text { MOBILITY }_{\mathrm{it}-1}\right)+\mathrm{AUX}_{\mathrm{it}}+\mathrm{year}_{\mathrm{t}}
\end{aligned}
$$

Where CAX is the current account excluding net investment income, NPFX is net private flows excluding net investment income, NOF is net official flows, NOA is net official assets (stock) and MOBILITY is a measure of capital mobility, ranging from 0 to1. NOF_HIGHMOB is an interaction term between net official flows and a dummy that takes the value 0 when the relevant measure of capital mobility is below its median and 1 otherwise. NOA_HIGHMOB is an interaction term between net official assets and the same dummy. Auxiliary variables (AUX) include lagged PPP GDP per capita relative to the United States, the 10-year forward change in old-age dependency ratio, the lagged real GDP growth rate over the previous 5 years, net energy exports relative to GDP, and the cyclically adjusted fiscal balance relative to GDP.

Equation 2 presents the current account as a function of net official flows and other control variables. The coefficient 1 represents the effect of net official flows on the current account and the coefficient 2 allows for a differential effect when capital mobility is above its median value. The coefficient 1 represents the effect of lagged net official asset stocks on the current account and the coefficient 2 allows for a differential effect with higher capital mobility. The coefficient represents the direct effect of capital mobility on the current account, if any. The regressions include a standard set of controls for other potential determinants of the current account similar to those used in Gagnon $(2013,2014)$ and Bayoumi and Saborowski (2014). ${ }^{19}$

Equation 3 is a restatement of the link between official flows and the current account in equation 2 that takes advantage of the BOP identity: any effect of net official flows on the current account that is less than 1 must show up as a negative effect on net private flows. When net official flows have no effect on the current account $\left({ }_{1}=0\right)$ then they must cause a one-forone reduction of net private flows. Because of errors and omissions in the BOP data, these regressions are not identical. The bias from measurement error in net official flows in the

\footnotetext{
${ }^{18}$ The baseline sample is chosen such that all indicators of capital mobility are available for each observation included.

${ }^{19} \mathrm{We}$ do not include country fixed effects in most of our regressions because much of the identifying information comes from differences across countries. But we present a few regressions showing that most of our results are robust to including a full set of country effects.
} 
estimate of ${ }_{1}$ is downward in Equation 2 and upward in Equation 3, helping to put a range on its true value.

The dependent variable in Equation 2 excludes investment income from the current account in order to remove the influence of steady-state differences in stocks of net foreign assets. ${ }^{20}$ Countries with higher net foreign assets tend to have higher current accounts because of the associated net investment income. Previous research has shown that the stock of net foreign assets is a robust and important regressor when the dependent variable is the total current account and the coefficient on net foreign assets is typically in the range of 0.02 to 0.06 , which is close to real rates of return on portfolio assets. ${ }^{21}$ By excluding net investment income from the dependent variable, we eliminate the need to include the stock of net foreign assets as a regressor. ${ }^{22}$ This allows us to use the stock of net official assets, a subset of net foreign assets, to estimate the lagged effect of net official flows on exchange rates and current accounts, working through the portfolio balance channel. We confirm in variants of the basic regressions (not shown) that the results are robust to including the stock of net private foreign assets (constructed as the difference between net foreign assets and net official foreign assets); the stock of net private foreign assets is no longer an important regressor after net investment income is excluded from the dependent variable and is often insignificant in the regressions.

In order to minimize the effect of outliers, we weight the observations in most of our regressions by each country's share of world GDP, but we also present some unweighted regressions to show robustness. Weighting by GDP is appropriate if a country's ratio of current account to GDP is interpreted as an average of the current account ratios of individual economic agents. Larger countries have less noise and idiosyncratic movements in their data than smaller countries and thus deserve greater weight. However, just two countries - the United States and the euro area ${ }^{23}$ - account for nearly half of global GDP. As these two countries are unusual in having close to zero net official flows and are the dominant issuers of reserve assets, we exclude them from most of our regressions, but we run some robustness regressions, with and without GDP weights, in which we include both. Our results are qualitatively robust to including these two countries.

\footnotetext{
${ }^{20}$ In order to be consistent with the BOP identity, net investment income is also subtracted from the dependent variable in Equation 3.

${ }^{21}$ Because rates of return on foreign assets are close in magnitude to growth rates of GDP, net investment income is roughly equal to the size of current account surplus needed to keep the ratio of net foreign assets to GDP constant.

${ }^{22}$ In deviations from a steady-state path, net foreign assets might be expected to have a negative effect on the current account through a wealth effect on consumption and imports. In practice, the coefficient on net foreign assets is usually positive and never significantly negative.

${ }^{23}$ We treat the 11 original members of the euro area plus Greece (which joined in 2001) as a single country because they shared common monetary and exchange rate policies over almost our entire baseline sample period (19952010). We treat countries that joined in 2007 and later as independent countries throughout. Of course, the euro area is technically not a country, but that is a convenient term for the cross-section units of our analysis.
} 
A key empirical issue is the potential endogeneity of official flows to shocks to current account balances and net private flows. Endogenous movements are most likely to arise from attempts to stabilize the exchange rate in the face of trade or financial market shocks. On the other hand, examples of exogenous movements in official flows include increasing holdings of foreign assets for precautionary reasons, saving resource revenues for future generations, borrowing for economic development, and achieving economic growth through higher net exports. Gagnon $(2012,2013)$ shows that endogeneity through stabilization of the exchange rate leads to a positive bias of the coefficient on net official flows if current account shocks dominate and a negative bias if private financial shocks dominate. Conventional wisdom suggests that financial shocks are important; witness the complaints from central banks in emerging markets about private capital flows driven by monetary policy in advanced economies. Aizenman (2006) finds that current account balances are more stable in countries with larger stocks of official reserves, corroborating the view that official flows move to offset shocks to private flows and stabilize the current account. Thus, it is likely that the coefficient on net official flows is biased downward. However, Ghosh, Ostry, and Tsangarides (2012) find that motivations for official flows shift over time and across countries, suggesting that the bias may not be constant over time and across countries.

We use instrumental variables to address the potential endogeneity of net official flows to shocks to current account balances and net private flows. The challenge is to isolate the variation in net official flows that is not driven by shocks that simultaneously drive the current account and/or private financial flows. Valid instruments must reflect exogenous motives for reserve accumulation.

Gagnon (2013, 2014) and Bayoumi and Saborowski (2014) used sets of instruments that include country dummies interacted with the lagged ratio of gross official assets to imports of goods and services as instruments. Months of import cover is a common metric for adequacy of foreign exchange reserves. The intuition is thus to capture the variation in net official flows that is related to country-specific precautionary motives governing the desired stock of reserves. One major drawback with this set of instruments is the resulting very large instrument count and the attendant risk of over-fitting. What is more, the import cover may not be a good proxy for some country's desired stocks of foreign reserves. Finally, in countries with very persistent current account shocks, country dummies may not succeed in fully dealing with a potential endogeneity bias. We nevertheless use this set of instruments as part of our robustness checks.

Our preferred set of instruments aims to more carefully reflect country-specific motives to accumulate reserves unrelated to exchange rate or current account developments without the profligate use of country-specific intercepts and slope coefficients. The instruments are defined in Table 1. The IMF dummy and its interaction with import cover follow the intuition that countries under IMF programs, and especially those with low import cover, may be more prone to accumulate reserves for precautionary reasons. The emerging markets dummy and its interaction with relative GDP per capita, in turn, proxy for mercantilist motives: emerging markets may be more prone to accumulate reserves than advanced markets especially when they 
are at an early stage of development. ${ }^{24}{ }^{25}$ Similarly, countries with SWFs in place are likely to have taken a forward looking decision to save; this decision would have stronger implications for reserve accumulation the higher are a country's resource revenues. ${ }^{26}$

\section{BASELINE REgRESSION RESUlTS}

This section describes the results of estimating Equations 2 and 3 using two-stage least squares using our preferred set of instruments described in Table 1. Tables $2 \mathrm{a}$ and $2 \mathrm{~b}$ display estimates using each of the nine measures of capital mobility shown in Figures 3 through 5. In order to compare goodness of fit across different measures of capital mobility, all regressions are run on the same set of observations that are common to all measures. The baseline sample is thereby de-facto restricted to the period 1995-2010. The baseline sample excludes the United States, the euro area, and all low income economies. As discussed in the previous section, we also drop countries with SWFs whose asset purchases cannot be accounted for and we use weighted least squares with GDP weights. $^{27}$

Note that we add one to the estimated coefficients on the net official flows term in the tables for all regressions in which net private financial flows (NPFX) is the dependent variable. As illustrated in Equation 3, adding one to the coefficient gives us an estimate of ${ }_{1}$, the coefficient on the net official flows term in a regression in which the current account is the dependent variable.

The auxiliary variables included in the regressions are relatively standard in the literature and are similar to the ones used in Bayoumi and Saborowski (2014) and Gagnon (2012, 2013). Except for relative PPP GDP per capita, the coefficients on the auxiliary variables all have the expected signs and are in the range found by previous studies. The unexpected negative effect of relative PPP GDP per capita is small and is not significant in some cases. An increase in relative GDP of 10 percentage points is estimated to reduce the current account by 0.2 to 0.5 percent of GDP.

\footnotetext{
${ }^{24}$ The EM dummy could be an inadequate instrument to the extent that EMs persistently accumulated reserves over the sample period because of persistent ToT shocks which we do not control for. We address this concern in the robustness section.

${ }^{25}$ Note that relative GDP per capita by itself is also included as a control in both the first and the second stage regression.

${ }^{26}$ Higher energy exports may also lead to higher current account balances. But note that energy exports are included as controls in both the first and the second stage regression.

${ }^{27}$ The euro area and the United States have very low net official flows and stocks in all years, providing little information to identify an effect on the current account when the sample is dominated by these countries. Some countries with large current accounts and large SWF flows do not include their SWF flows in standard data; including these countries in the sample with erroneous data on net official flows leads to biased estimates. Small and poor countries sometimes have volatile data owing to idiosyncratic reasons that are not well controlled by our auxiliary variables; weighting observations by GDP and/or omitting low-income countries helps with this problem. We explore robustness of our results to these and other factors in the next subsection.
} 
The first stage results are encouraging in that our instruments appear relevant. The instruments generally show the expected signs - illustrated in Table 1-in the first stage regressions when they are individually significant. In the case of the net official flows term, the F-test statistic takes values between 7.9 and 13.1 in our baseline regressions in Tables $2 \mathrm{a}$ and 2b; the null hypothesis that our instruments are irrelevant is comfortably rejected in all of the regressions. Similarly, the Angrist-Pischke first stage chi-squared statistic rejects the null that the net official flows term is unidentified almost throughout. We find similar evidence in the case of the interaction between the net official flows term and the various measures of capital mobility for which the F-test statistic takes values between 5.6 and 11.7.

Moving to the second stage estimation results, columns 1 and 2 of Table 2a display results using the Chinn-Ito measure of capital mobility. Column 1 is based on a regression of the current account excluding investment income (Equation 2) and column 2 is based on a regression of net private flows (Equation 3). The estimated effect of net official flows on the current account when capital mobility is below the median $\left({ }_{1}\right)$ is 0.66 in column 1 and 0.71 in column 2. The coefficient on the interaction term between net official flows and the capital mobility dummy ( 2 ) captures the difference in the effect of net official flows between low-mobility and high-mobility situations. The overall effect of net official flows when mobility is above the median is the sum of these two coefficients, or 0.11 in column 1 and 0.03 in column 2 .

The coefficients 1 and 2 reflect the immediate effect of net official flows on the current account. However, because official flows have permanent effects on the relative supplies of assets in different currencies, they are likely to have long-lasting effects on exchange rates and current accounts through the portfolio balance channel. These effects are captured in the coefficients on the lagged stocks of net official assets. An interesting result is that the total effect of lagged official assets is positive and significant in most regressions only when capital mobility is above the median.

Taking these results together, it appears that when capital mobility is high, net official flows have a smaller immediate impact on the current account but a larger lagged impact through the reserves stock. This may occur because international capital mobility allows better smoothing short-run fluctuations in net official flows, but the greater volume of private flows increases the importance of portfolio effects. When private flows are tightly restricted, agents have less ability to maintain diversified portfolios and so accumulated stocks of official assets have less effect. A competing hypothesis with the opposite implication could have been that investors have tighter exposure limits in countries that are less integrated into the global financial system.

The finding that interventions have smaller contemporaneous but larger lagged effects in countries with high capital mobility may at first appear surprising but is line with intuition. Low mobility implies that the flow effect is strong because investors cannot take advantage of arbitrage opportunities to offset official flows. Under low mobility, portfolio rebalancing effects - which require capital to be mobile - exist but matter less as the flow effect dominates. With high mobility, the immediate effect of interventions is greatly attenuated, but the implied 
changes in relative asset supplies have a small but persistent effect through the portfolio balance channel. It is important to note that the flow coefficient, especially under low mobility, is much larger than the lagged stock coefficient under either low or high mobility.

In both columns 1 and 2, for countries with high capital mobility, a one percentage point higher lagged stock of net official assets increases the current account by 0.07 percent. Because stocks of official assets typically are larger than flows, this is an important effect. For example, a relatively open economy with net official assets equal to 10 percent of GDP would have a current account that is higher by 0.7 percent of GDP than a comparable country with 0 net official assets, even if net official flows were the same in both countries. Because we have excluded net investment income from the dependent variable, this effect must reflect a lasting effect through the exchange rate rather than simply the earnings on official assets.

The coefficient on the Chinn-Ito measure itself is positive but very small. This is not necessarily surprising, as there is no a priori presumption that capital controls should on average either increase or decrease the current account balance independently of official financial flows. $^{28}$

Turning to columns 3 to 6 , we see that the variables of interest remain significant in the regressions using the Fund index and the Quinn measure, and the coefficients retain the expected signs. The effect of net official flows on current accounts is somewhat higher on average with these measures than with the Chinn-Ito measure. The total effect of net official flows under high mobility increases to between 0.15 and 0.21 , while the coefficient under low mobility is roughly unchanged, between 0.59 and 0.77 . The coefficients on the lagged stock variable are very similar to those found when using the Chinn-Ito measure. Once again, the direct effect of mobility on the current account is essentially zero.

Turning to the institutional measures of capital mobility, columns 7 and 8 display results using the ICRG composite risk index. The interaction terms are not significant in the two regressions but the coefficients remain correctly signed. The effect of net official flows is again around 0.7 in the low mobility situation but when mobility is above the median, the total effect, at about 0.4 , is somewhat higher than in previous regressions. There is once again no significant effect of lagged official stocks in the low mobility case and a moderately large effect with high mobility. The ICRG composite risk index itself has no effect on the current account.

The institutional measure with the best regression fit $\left(\mathrm{R}^{2}\right)$ is the regulatory quality index (columns 9 and 10). The net official flows terms along with their interaction with capital

\footnotetext{
${ }^{28}$ This presumption holds when controls are applied equally on outflows and inflows. Controls that are focused on inflows would tend to increase current accounts and controls that are focused on outflows would tend to reduce current accounts. Here we use the overall measures of capital controls. We note that for the coefficient of primary interest, the effect of net official flows on current accounts, both inflow and outflow controls would be expected to increase it.
} 
mobility are all highly significant. Their coefficients have the expected signs, and the coefficient magnitudes are almost identical to those in the Chinn-Ito regressions. The lagged stock effect under high mobility is slightly higher than in previous regressions and not significantly different from zero in the low mobility case. Regulatory quality has a significant negative direct effect on the current account, but this effect is rather small economically given the relatively small range of this variable. The alternative institutional indicator of the rule of law (columns 11 and 12) is the indicator with the worst regression fit in Table 2 . While the net official flows term and its interaction are significant and correctly signed in both regressions, three of the coefficients become larger than one. The average effect of net official flows, at 0.6 , takes a value that is higher than in the case of all other mobility measures. What is more, somewhat surprisingly, the effect of the lagged stock of foreign assets falls to negative territory with low mobility.

Columns 1 through 6 of Table $2 \mathrm{~b}$ focus on financial market measures of capital mobility. The results are remarkably similar to previous regressions in terms of the average effect of net official flows, although the interaction term is not significant in the case of the financial share measure discussed in Box 1. The ratio of BOP financial flows to GDP (columns 3 and 4) turns out to be the best fitting of all nine individual measures of capital mobility. Here we again find evidence in favor of an important role for capital mobility as the effect of net official flows falls from $(0.47$ to 0.57$)$ in the low mobility case to around 0.2 under high mobility. The official stock effect is once again zero in the low mobility case and around 0.05 with high mobility. The direct effect of the BOP financial ratio to GDP is not significant. The final mobility measure is the ratio of bank assets to GDP (columns 5 and 6). The results here are fairly similar to those for the BOP financial flows to GDP measure.

The remaining columns of Table $2 \mathrm{~b}$ attempt to construct a better overall measure of capital mobility by extracting information common to the various indicators. Columns 7 and 8 display results based on the first principal component of all nine mobility measures. Columns 9 and 10 are based on the first principal component of the best measures within each sub-group. ${ }^{29}$ Columns 11 and 12 display a variant of the measure used in columns 9 and 10, substituting the financial share of BOP transactions for the ratio of BOP financial flows to GDP and the ICRG financial risk index for the regulatory quality index. This final measure is the overall best fitting measure.

The results across all three principal component measures are broadly similar in terms of the average effect of net official flows on the current account. Focusing on the best-fitting "alternate" measure, the effect of net official flows with low capital mobility is 0.46 to 0.51 . This effect declines significantly to around 0.21 to 0.25 with high mobility. The effect of net official asset stocks is insignificant with low mobility and 0.03 to 0.04 higher with high mobility. The

\footnotetext{
${ }^{29}$ Among the legal measures of capital controls, the best fitting measure is the Fund index. The regulatory quality index is the best fitting among the institutional quality measures. And the best fitting financial market measure is the ratio of BOP financial flows to GDP.
} 
direct effect of mobility on the current account is negative and significant but relatively small. An increase in capital mobility equal to half of the total range between the lowest value and the highest value in the sample would lower the current account by 0.4 percent of GDP.

The green bars in Figure 6 display the average effects of net official flows on the current account across all the regressions of Tables $2 \mathrm{a}$ and $2 \mathrm{~b}$. The first bar, labeled High, is the sum of 1 and 2 , which is the effect under high capital mobility. The second bar, labeled Low, is 1 , which is the effect under low capital mobility. The bars in the other colors refer to alternative sets of regressions discussed below. On average across the regressions in Tables $2 \mathrm{a}$ and $2 \mathrm{~b}$, each dollar of net official flows raises the current account 18 cents with high capital mobility and 66 cents with low capital mobility, for an average effect of 42 cents.

\section{Robustness to SAMPLE AND SPECIFICATION}

Tables $3 \mathrm{a}$ and $3 \mathrm{~b}$ show the results from the same specification as in Tables $2 \mathrm{a}$ and $2 \mathrm{~b}$ except that we do not use instruments to identify the effect of net official flows on current accounts. The tables show that both the net official flows term and its interaction generally are significant with correctly signed coefficient. What is more, the coefficients are more stable across regressions than when using two-stage least squares. Interestingly, the effect of net official flows on the current account is similar to the results found in Tables $2 \mathrm{a}$ and $2 \mathrm{~b}$ in the high mobility case but is significantly smaller in the low mobility case. The blue bars in Figure 6 illustrate this finding by averaging the relevant effects across all regressions in the tables. While the average impact under low mobility is 0.66 in the case of the instrumented regressions (the green bars), it falls to half of that in the regressions without instruments (the blue bars). The average effect of net official flows on current accounts is thus 24 cents to the dollar in the regressions without instruments compared to 42 cents to the dollar in the two-stage least squares regressions in Tables $2 \mathrm{a}$ and $2 \mathrm{~b}$. This result is consistent with the idea that the bias in a regression without instruments when net official flows move to stabilize the exchange rate tends to be negative because financial shocks to the exchange rate are more important than trade shocks. Finally, the lagged stock of official assets is now often significant as a determinant of the current account independently of capital mobility. However, the magnitude of the effect remains broadly the same.

Tables $4 \mathrm{a}$ and $4 \mathrm{~b}$ again show the same set of regressions as in the previous tables but use two-stage least squares with the alternative set of instruments described in Table 1 . The instruments include country dummies as well as their interaction with the lagged ratio of gross reserves to imports of goods and services. The net official flows term and its interaction with capital mobility are once again significant in almost all regressions. The coefficients are correctly signed and are more stable than in our preferred set of regressions. As illustrated by the red bars in Figure 6, the effect of net official flows under high mobility is on average only slightly lower than that found in Tables 2 and 3; the average effect in the low mobility case, in turn, is 0.50 and thus lies between that found in the case of the regressions without instruments and those with the preferred instrument set. In the high mobility case, on the other hand, the coefficient shrinks to only slightly over 0.10 . 
Tables 5 through 7 contain robustness checks departing from our baseline two-stage least squares regressions in Table 2. Table 5 displays regressions using the Quinn measure of capital controls, which fit nearly as well as the Fund measure and has more observations; Table 6 uses the BOP financial flows to GDP measure, which had the best fit among individual indicators, and Table 7 employs the alternate principal components measure of capital mobility, which had the overall best fit in Table 2. The results in these tables should be compared to the respective baseline regressions in Table 2.

Columns 1 and 2 in all three tables reflect the baseline regressions in Table 2 but add the growth rate of nominal GDP to the specification as an additional control. In the interest of identifying sterilized rather than unsterilized intervention, the idea is to better control for changes in the monetary policy stance. ${ }^{30}$ Looking at Table 5 , the coefficients are almost unchanged from those in columns 5 and 6 of Table $2 \mathrm{a}$. The same is the case for Tables 6 and 7 and the corresponding results in columns 3 and 4 and columns 11 and 12 of Table $2 b$. Although the interaction terms between net official flows and capital mobility now attain somewhat lower significance levels, the coefficient signs and magnitudes are close to unchanged.

Columns 3 and 4 show results in which the sample is augmented to include both the United States and the euro area. The coefficient on official stocks is now not only significant under high mobility but also under low mobility, with an unchanged magnitude. The net official flows term and its interaction with capital mobility mostly remain significant with the correct signs. However, the coefficients magnitudes differ. The total effect under high mobility falls to around zero in all three tables while the effect under low mobility falls from around 0.7 in Table 2 , to between 0.2 and 0.4 . It may not be very surprising that results change with the inclusion of the euro area and the United States in the weighted regressions since they account for almost half of global GDP. What is more, they have very low net official flows and stocks in all years, providing little information to identify an effect on the current account when the sample is dominated by these countries. Finally, the United States and the euro area are the main reserve currency issuers and thus their current accounts are potentially strongly affected by other countries' net official flows. ${ }^{31}$

The regressions in columns 5 and 6 of Tables 5-7 again include the United States and the euro area but drop the GDP weights. Here the results differ significantly according to the mobility measure used, but an economically important effect of net official flows and/or lagged official stocks on current accounts remains a broad theme. The result that the effect of net official flows on current accounts is conditional upon capital mobility continues to hold strongly in Tables 5 and 7 but not in Table 6 . The reduced stability and significance of the results may be

\footnotetext{
${ }^{30}$ The nominal GDP growth rate is calculated based on 5-year moving averages to reduce the influence of outliers. The results are also robust to using growth rate of bank assets instead (not shown here).

${ }^{31}$ Bayoumi and Saborowski (2014) find that the effects of capital outflows related to reserve accumulation can be found largely in the current account of the United States, with limited evidence for an effect on other countries.
} 
explained by the fact that the analysis now gives more weight to very small countries with potentially volatile data owing to idiosyncratic reasons that are not well controlled for by our auxiliary variables. Weighting observations by GDP helps with this problem.

Columns 7 and 8 add country fixed effects to the baseline regression to account for possible country-specific differences in current accounts that are not controlled by our independent variables. ${ }^{32}$ The result that the effect of net official flows on the current account is conditioned by capital mobility continues to hold. However, coefficient magnitudes become substantially larger when only within group variation is considered. In the Quinn regressions (Table 5), the net official flows effect increases to between 0.78 and 1.12 under low mobility. Similarly, the effect increases to 0.85 to 0.92 in Table 6 and 0.90 to 0.91 in Table 7 . The effect of the lagged stock of reserves, in turn, falls to between 0.01 and 0.03 in all three tables and is moderately negative in the case of low mobility.

Country heterogeneity may be especially large between emerging markets and advanced markets as a group. Columns 9 and 10 address this concern by dropping advanced markets from the sample which reduces the number of observations by about thirty percent. Although coefficients continue to show the expected signs, coefficient magnitudes change compared to the baseline regressions. The average effect of net official flows is now smaller than in the baseline in the case of the Quinn regression (Table 5) but larger than in the baseline in the case of the other two measures (Tables 6 and 7). The net official flows term is no longer significant in the regressions while the interaction term mostly retains significance. The reason why the results come out weaker in this robustness check is that two of our instruments (the emerging markets dummy and its interaction) are redundant in a sample that is restricted to emerging market economies. Running the same robustness checks without instruments or using the alternative instrument set gives results that are almost completely unchanged compared to the baseline, and all variables of interest remain significant (not reported).

Columns 11 and 12 test whether accounting for different monetary regimes has an impact on our results. Specifically, we introduce a dummy in the regression that takes the value one in the case of flexible exchange rate regimes and zero otherwise. ${ }^{33}$ In order to allow for the total effect of net official flows on current accounts to be conditioned upon the exchange rate regime in place, we interact both the net official flows term and the interaction term with capital mobility with the regime dummy. Similarly, both the lagged stock term and its interaction with capital mobility are interacted with the regime dummy. The results suggest that countries with

\footnotetext{
${ }^{32} \mathrm{We}$ did not choose fixed effects regressions as the baseline specification because persistent cross-country differences in reserve accumulation would make cross-country variation valuable in identifying the true effect of net official flows on current accounts. What is more, much of the information contained in our preferred set of instruments reflects cross-country differences in the propensity to accumulate reserves.

${ }^{33}$ Exchange rate regimes are differentiated according to Ilzetzki, Reinhart and Rogoff (2008). The dummy takes the value one when the coarse classification is either 3 or 4.
} 
flexible exchange rate regimes have more negative current accounts (by 2-4 percent of GDP). In addition, in all regressions the interaction term between net official flows and capital mobility, interacted with the regime dummy, carries a negative coefficient, and the interaction between the net official flows term and the regime dummy carries a positive coefficient. The results are thus suggestive of a greater role for capital mobility in conditioning the effectiveness of intervention when exchange rates are fixed.

Columns 13 and 14 drop all Asian countries from the baseline sample to address the concern that the results may be driven by this region. However, the results remain broadly unchanged in spite of the fact that the sample size drops by about a quarter. Columns 15 and 16 restrict the sample to the pre-2008 period to ensure that the results are not affected by the global financial crisis. This reduces the sample size by about 20 percent. Once again, the main results in this paper survive. Columns 17 and 18 add low income countries to the sample. This adds about a quarter to the baseline sample size but does not appear to have a systematic effect on our results although the average effect of net official flows falls moderately in some cases. Finally, columns 19 and 20 remove the common sample restriction and thus use the full sample for which each respective capital mobility measure is available. This adds between 33 (Table 7) and 48 percent (Table 6) to the sample size. In the case of the Quinn regressions (Table 5), the results appear almost completely unchanged compared to the baseline. Coefficients retain the expected signs and are broadly comparable in terms of magnitude to the baseline. The lagged official stock effect is broadly unchanged in all three tables.

Columns 21 and 22 add the terms of trade (ToT) to the baseline specification as an additional control. The motivation is that one of our instruments - the EM dummy - could be inadequate to the extent that EMs persistently accumulated reserves over the sample period because of persistent ToT shocks which we do not control for. We experimented with including the overall ToT index as well as a purely commodity based ToT index as well as detrended versions of these variables to isolate the cyclical component. The only term that turned out to be frequently significant with the correct positive sign is the overall ToT index. Including the term leaves the core results of the paper broadly unaffected.

Columns 23 and 24 add an interaction of relative GDP per capita with mobility to the set of controls. The objective is to address the concern that the relative GDP per capita variable shows a negative coefficient in the baseline regressions, violating the intuition that capital should flow from rich to poor countries. While the interaction term often takes the correct positive sign, the average impact of relative GDP per capita remains negative. The main results of the paper are not affected in a systematic way although the average effect of net official flows on current accounts falls in Tables 5 and 7 and increases in Table 6.

\section{Comparison to Previous Studies}

On average, across all regressions in Table 2 and across regimes of both high and low capital mobility, the effect of net official flows on the current account is 42 cents for each dollar of 
intervention. Putting this finding into context with previous studies, the effect is larger than in Bayoumi and Saborowski (2014) and IMF (2012, 2013), but smaller than in Gagnon (2013) and comparable to Gagnon (2012). Contrary to Gagnon (2012, 2013), we confirm the findings of Bayoumi and Saborowski (2014) and IMF $(2012,2013)$ that capital mobility has an important influence on the effect of net official flows on the current account. Unlike the latter studies, however, we find that net official flows may have important effects even when capital is highly mobile, although estimates of effects are sensitive to sample and specification. A common finding in all of these studies is that capital mobility typically has a small to moderate negative direct effect on the current account. An important new finding in this study is the effect of lagged official flows as captured by the coefficient on the lagged stock of net official assets. ${ }^{34}$ The stock effect is typically larger under high capital mobility than under low mobility.

There appear to be several factors explaining the differences in results across studies. An important factor is the choice of instruments; another is the country sample chosen. ${ }^{35}$ In addition, most previous studies (IMF (2012, 2013), Bayoumi and Saborowski, 2014) focus only on a variant of Equation 2, in which the coefficient on net official flows suffers from the standard downward bias owing to measurement error. Estimating not only Equation 2 but also Equation 3 balances out the results because measurement error introduces a bias in the opposite direction in Equation 3. Basing the analysis on current accounts excluding net investment income allows us to identify a lagged effect of official flows operating through the lagged stock of net official assets.

Even after controlling for differences in capital mobility, coefficients are somewhat sensitive to which countries and years are included in the analysis. Many countries have very low net official flows and stocks in all years, providing little information to identify an effect on the current account when the sample is dominated by these countries. Some countries with large current accounts and large SWF flows do not include their SWF flows in standard data; including these countries in the sample with erroneous data on net official flows leads to biased estimates. Small and poor countries sometimes have volatile data owing to idiosyncratic reasons that are not well controlled by our auxiliary variables; weighting observations by GDP and omitting low-income countries helps with this problem.

Endogeneity of net official flows to shocks to current accounts and private financial flows leads to biased coefficient estimates, and the direction of bias varies across countries and

\footnotetext{
${ }^{34}$ Gagnon (2013) and Bayoumi and Saborowski (2014) found larger effects of net official flows using data averaged over five-year periods compared to annual data. (IMF $(2012,2013)$ used annual data.) We conjecture that five-year flow data may conflate some of the stock effect with the flow effect.

${ }^{35}$ The definition of the net official flows term is another important factor. IMF $(2012,2013)$ define the term as the change in the stock of reserves. This measure is potentially subject to valuation effects and does not account for flows in official assets and liabilities besides reserve assets (net portfolio and other assets including SWF related flows). Bayoumi and Saborowski (2014) and Gagnon $(2012,2013)$ include net official other flows but also do not include net official portfolio flows.
} 
years. Instrumental variables may over-fit, leaving biases unadjusted, or they may under-fit, creating new biases from measurement error and unstable coefficients in the second stage regressions. The results in this paper suggest that regressions without instruments will lead to estimates of the total effect of net official flows on the current account that are biased downward. While the effect of net official flows under high mobility is similar between all regressions with and without instruments, it is the effect under low mobility that shows a lot of variation. The effect is 32 cents to the dollar without instruments, 50 cents to the dollar with our alternative set of instruments - which is similar to that used in Bayoumi and Saborowski (2014) and Gagnon (2012, 2013) — and 66 cents to the dollar for our preferred set of instruments. ${ }^{36} 37$

\section{ILLUSTRATION OF FitTED MODEL FOR INDIVIDUAL COUNTRIES}

Table 8 illustrates the importance of the variables central to our analysis for current accounts in specific country examples. It presents data and estimated contributions to the current account in percent of GDP based on our baseline model, relative to world averages. Specifically, it presents the overall effects of net official flows, official stocks, and capital mobility for specific countries and years, based on the averages of the coefficients shown in columns 11 and 12 of Table $2 \mathrm{~b}$. All data are expressed as deviations from unweighted averages across countries in percent of GDP. The estimated contributions of each variable listed in the headers are the variable coefficient times the variable value for that country and year. The estimated contributions for the current account are the sums of the contributions of the other variables listed. Any difference between the current account data and estimated contributions reflects the effects of the auxiliary variables and the residual error.

The first row of Table 8 shows that China's current account excluding net investment income was more than 6.2 percentage points larger than that of the average country in 2007. China's net official flows were 9.4 percentage points higher than those of the average country. Because China has low capital mobility, the interaction term of net official flows with the mobility dummy is zero, which was 2.4 percentage points lower than that of the average country. China's lagged stock of net official assets was 15.2 percentage points higher than that of the average country, but the interaction term with mobility is zero, which was 10.9 percentage points below average. Finally, China's capital mobility was below average as well. ${ }^{38}$ China's external

\footnotetext{
${ }^{36}$ Gagnon (2013) has a second instrument set without country-specific intercepts and slopes. This set often yields large estimates of the effect of net official flows, but the first-stage fit is poor and the coefficients are highly unstable across samples.

${ }^{37}$ IMF $(2012,2013)$ also uses a set of instruments similar in spirit, but even larger than, our alternative set (which may run the risk of over-fitting). The instrument set includes country-specific intercepts and slopes defined by potential proxies reserve accumulation motives including M2/GDP, U.S. interest rates, and the trend in global reserve accumulation.

${ }^{38}$ To create Table 8 , the mobility measure was multiplied by 100 to be commensurate with other data expressed in percentage points.
} 
policies as a group explain 5.3 percent of GDP or nearly all of its current account, of which most owes to China's net official flows in 2007.

The next section displays analogous results for Singapore, which had an even larger current account in 2007 but was characterized by high capital mobility. Singapore engages in massive net official flows and has an enormous stock of net official assets. Official flows, stocks, and capital mobility explain just over half of Singapore's current account. Singapore's fiscal surplus and rapid aging explain another 4.1 percentage points of its current account according to the model (not shown here). For Singapore, the lagged official stock has an important impact, explaining more of the current account than official flows.

The two largest countries, the United States and the euro area, had current accounts below the global average in 2007. These countries issue the world's main reserve currencies and do not have significant net official flows or stocks. Because most countries did have positive net official flows and stocks in 2007, the data for these two countries are below the global averages. These are also high capital mobility countries. The table shows that about a third of the US current account is explained by its net official flows, stocks, and capital mobility, with most of the difference in a large residual. ${ }^{39}$ For the euro area, however, the model somewhat overpredicts the current account deficit, and the error is compounded by the auxiliary variables, which also predict a deficit. These results are consistent with Bayoumi and Saborowski (2014), who find that the effect of global reserve accumulation on the current account deficits of nonaccumulating countries is almost exclusively focused on the United States.

The final two sections of the table examine countries that were intervening to support their currencies during periods of current account deficits. Romania in 2009 had a current account 4 percentage points below average and net official flows nearly 8.4 percentage points below average. The model almost exactly explains Romania's current account deficit that year through official flows, stocks, and capital mobility. This suggests that, if Romania had stopped intervening and allowed the leu to depreciate, it would not have had a current account deficit. The results are broadly comparable, but a bit weaker, for Hungary in 2006.

\section{Conclusion}

We find that net official flows have a large but plausible effect on current account balances. This result is robust to an array of samples, specifications, and estimation techniques. The estimated effects are larger with instrumental variables (42 cents to the dollar on average compared to 24 without instruments), reflecting a possible downward bias in regressions without instruments owing to an endogenous response of net official flows to private financial flows. While the effect of net official flows under high mobility is similar between all regressions with and without instruments, it is the effect under low mobility that shows much variation. The effect under low

\footnotetext{
${ }^{39}$ The results for the United States and the euro area are based on Table $2 \mathrm{~b}$ even though the estimation sample excluded these countries.
} 
mobility is 32 cents to the dollar on average in regressions without instruments and 66 cents to the dollar in the case of our preferred set of instruments.

We also find that the impact of net official flows is importantly affected by the extent of international capital mobility. Nearly all of the various measures we employ show that the effect of net official flows on the current account declines as mobility increases (from 66 cents to the dollar to 18 cents to the dollar in the baseline). These results are robust to varying samples and specifications. However, coefficient magnitudes for lower capital mobility are sensitive to the countries and years included in the analysis. While our preferred specification predicts an average effect of 42 cents to the dollar, our robustness checks illustrate that the confidence interval around this number remains rather wide.

A further result is that there is an important effect of lagged net official flows, captured by the coefficient on the lagged stock of net official assets. We believe this effect operates through the portfolio balance channel. Persistent changes in the relative supplies of assets in different currencies have persistent effects on exchange rates and current account balances. This effect often, but not always, appears to increase with capital mobility, probably indicating that the portfolio channel is less important when private flows are tightly restricted. There is also some tradeoff across samples and specifications in the estimates of the net official flow and net official stock effects. When flow effects are estimated to be larger, stock effects typically are estimated to be smaller.

An important policy implication of these results is that persistent large net official outflows in some countries are an important contributor to sustained current account surpluses. Even in cases in which official flows are motivated by a desire to stabilize the exchange rate, a policy change to cease net official flows and allow the exchange rate to appreciate would lead to a significant decline in the current account balance. Of course, in order to offset the loss of net external demand and keep output at potential, these countries would need to loosen monetary and/or fiscal policy. To answer the question we posed in the introduction, there is evidence that net official financial flows in some countries, especially those with low capital mobility, are frustrating global current account adjustment.

Finally, the direct effect of capital mobility on current accounts is often quite small, but is generally negative and sometimes significantly so. Opening of capital markets tends to favor borrowing over lending, other things equal. 


\begin{tabular}{|c|c|c|}
\hline \multicolumn{3}{|c|}{ Table 1. Definition of Instruments } \\
\hline Instrument & Definition & $\begin{array}{l}\text { Expected impact } \\
\text { on net official }\end{array}$ \\
\hline \multicolumn{3}{|l|}{ Preferred set } \\
\hline IMF program dummy & $\begin{array}{l}\text { Takes the value one for country A if country A has an IMF } \\
\text { program and the year is not the year of approval; takes the value } \\
\text { zero otherwise. }\end{array}$ & Positive \\
\hline $\begin{array}{l}\text { Interaction of IMF program dummy with } \\
\text { lagged import cover }\end{array}$ & $\begin{array}{l}\text { The interaction is the product of the IMF program dummy and the } \\
\text { lagged stock of gross reserves divided by imports of goods and } \\
\text { services. }\end{array}$ & Negative \\
\hline Emerging market dummy & $\begin{array}{l}\text { Takes the value one for emerging markets and the value zero } \\
\text { otherwise. }\end{array}$ & Positive \\
\hline $\begin{array}{l}\text { Interaction of emerging market dummy with } \\
\text { Relative PPP GDP per capita }\end{array}$ & $\begin{array}{l}\text { The interaction is the product of the EM program dummy and the } \\
\text { Relative PPP GDP per capita variable defined in the Appendix. }\end{array}$ & Negative \\
\hline SWF dummy & $\begin{array}{l}\text { Takes the value one if a country has an oil-based sovereign } \\
\text { wealth fund and the value zero otherwise. }\end{array}$ & Positive \\
\hline $\begin{array}{l}\text { Interaction of SWF dummy with energy } \\
\text { exports }\end{array}$ & $\begin{array}{l}\text { The interaction is the product of the SWF dummy and the energy } \\
\text { exports variable defined in the Appendix. }\end{array}$ & Positive \\
\hline \multicolumn{3}{|l|}{ Alternative set } \\
\hline $\begin{array}{l}\text { Interaction between country dummies and } \\
\text { the lagged reserve ratio to imports }\end{array}$ & $\begin{array}{l}\text { The interaction between each country dummy and the lagged } \\
\text { ratio of gross official assets to imports of goods and services. }\end{array}$ & Negative \\
\hline
\end{tabular}




\begin{tabular}{|c|c|c|c|c|c|c|c|c|c|c|c|c|}
\hline \multicolumn{13}{|c|}{ Table 2a. Baseline Specification with Various Capital Mobility Measures and Preferred Set of Instruments (continued) } \\
\hline & Reg 1 & Reg 2 & Reg 3 & Reg 4 & Reg 5 & Reg 6 & $\operatorname{Reg} 7$ & $\operatorname{Reg} 8$ & $\operatorname{Reg} 9$ & Reg 10 & Reg 11 & $\operatorname{Reg} 12$ \\
\hline Dependent & CAX & NPFX & CAX & NPFX & CAX & NPFX & CAX & NPFX & CAX & NPFX & CAX & NPFX \\
\hline Mobility Measure & Chinn-Ito & Chinn-Ito & Fund & Fund & Quinn & Quinn & ICRG & ICRG & Reg. Qual. & Reg. Qual. & Rule of Law & Rule of Law \\
\hline \multirow{2}{*}{ Lagged relative PPP GDP pc } & $-0.05^{* * *}$ & $-0.05^{* * *}$ & $-0.03^{* * *}$ & $-0.03^{* * *}$ & $-0.04^{* * *}$ & $-0.03^{* * *}$ & $-0.05^{* * *}$ & $-0.05^{* * *}$ & $-0.03^{* *}$ & $-0.02^{* *}$ & $-0.04^{* * *}$ & $-0.04^{* * *}$ \\
\hline & 0.01 & 0.01 & 0.01 & 0.01 & 0.01 & 0.01 & 0.01 & 0.01 & 0.01 & 0.01 & 0.01 & 0.01 \\
\hline \multirow[t]{2}{*}{ Aging } & $2.31^{* * *}$ & $1.86^{* * *}$ & $2.41^{* * *}$ & $1.96^{* * *}$ & $2.26^{* * *}$ & $1.78^{* * *}$ & $2.52^{* * *}$ & $2.12^{* * *}$ & $2.77^{* * *}$ & $2.33^{* * *}$ & $2.22^{* * *}$ & $1.63^{* *}$ \\
\hline & 0.55 & 0.58 & 0.54 & 0.56 & 0.52 & 0.55 & 0.52 & 0.55 & 0.52 & 0.56 & 0.64 & 0.68 \\
\hline \multirow[t]{2}{*}{ Lagged Growth } & $-0.18^{* *}$ & $-0.29 * * *$ & $-0.15^{*}$ & $-0.28^{* * *}$ & $-0.16^{* *}$ & $-0.27^{* * *}$ & -0.09 & $-0.19 * *$ & -0.1 & $-0.22 * * *$ & -0.15 & $-0.29 * * *$ \\
\hline & 0.08 & 0.08 & 0.08 & 0.08 & 0.08 & 0.08 & 0.08 & 0.09 & 0.07 & 0.08 & 0.1 & 0.1 \\
\hline \multirow[t]{2}{*}{ Energy } & $0.15^{* * *}$ & $0.13^{* * *}$ & $0.15^{* * *}$ & $0.12^{* * *}$ & $0.15^{* * *}$ & $0.12^{* * *}$ & $0.17^{* * *}$ & $0.15^{* * *}$ & $0.16^{* * *}$ & $0.13^{* * *}$ & $0.17^{* * *}$ & $0.14^{* * *}$ \\
\hline & 0.03 & 0.03 & 0.03 & 0.03 & 0.03 & 0.03 & 0.02 & 0.02 & 0.03 & 0.03 & 0.04 & 0.05 \\
\hline \multirow[t]{2}{*}{ Fiscal } & $0.32^{* * *}$ & $0.28^{* * *}$ & $0.29 * * *$ & $0.24^{* * *}$ & $0.28^{* * *}$ & $0.24^{* * *}$ & $0.27^{* * *}$ & $0.22^{* * *}$ & $0.32^{* * *}$ & $0.28^{* * *}$ & $0.26^{* * *}$ & $0.21^{* * *}$ \\
\hline & 0.06 & 0.06 & 0.06 & 0.06 & 0.06 & 0.06 & 0.06 & 0.06 & 0.06 & 0.06 & 0.07 & 0.07 \\
\hline \multirow[t]{2}{*}{ Net official flows (NOF) } & $0.66^{* * *}$ & $0.71^{* * *}$ & $0.59^{* * *}$ & $0.69^{* * *}$ & $0.70^{* * *}$ & $0.77^{* * *}$ & $0.69 * *$ & $0.74^{* * *}$ & $0.62^{* * *}$ & $0.68^{* * *}$ & $1.03^{* * *}$ & $1.15^{* * *}$ \\
\hline & 0.15 & 0.16 & 0.14 & 0.15 & 0.15 & 0.16 & 0.29 & 0.28 & 0.17 & 0.18 & 0.25 & 0.27 \\
\hline \multirow[t]{2}{*}{ Interaction with Mobility dummy } & $-0.55^{* * *}$ & $-0.66 * * *$ & $-0.39 * *$ & $-0.54^{* * *}$ & $-0.49 * * *$ & $-0.62 * * *$ & -0.28 & -0.33 & $-0.54^{* * *}$ & $-0.68^{* * *}$ & $-0.89 * * *$ & $-1.08^{* * *}$ \\
\hline & 0.14 & 0.15 & 0.15 & 0.17 & 0.16 & 0.18 & 0.29 & 0.28 & 0.15 & 0.16 & 0.22 & 0.23 \\
\hline \multirow{2}{*}{ Lagged stock of official assets (NOA) } & 0.01 & 0.01 & 0.01 & 0.01 & 0 & 0 & -0.02 & -0.01 & -0.02 & -0.01 & $-0.07^{* *}$ & $-0.06^{*}$ \\
\hline & 0.02 & 0.02 & 0.02 & 0.02 & 0.02 & 0.02 & 0.02 & 0.02 & 0.02 & 0.02 & 0.03 & 0.03 \\
\hline \multirow[t]{2}{*}{ Interaction with Mobility dummy } & $0.06^{* * *}$ & $0.06^{* * *}$ & $0.05^{* *}$ & $0.05^{* *}$ & $0.06^{* * *}$ & $0.07^{* * *}$ & $0.07^{* * *}$ & $0.06^{* * *}$ & $0.08^{* * *}$ & $0.09 * * *$ & $0.13^{* * *}$ & $0.14^{* * *}$ \\
\hline & 0.02 & 0.02 & 0.02 & 0.02 & 0.02 & 0.02 & 0.02 & 0.02 & 0.02 & 0.02 & 0.03 & 0.03 \\
\hline \multirow[t]{2}{*}{ Mobility } & 0.01 & $0.01 *$ & $-0.01 *$ & 0.00 & 0.00 & 0.00 & 0.00 & 0.00 & $-0.01 * *$ & $-0.01 * *$ & $0.01^{* *}$ & $0.01^{* *}$ \\
\hline & 0.00 & 0.00 & 0.00 & 0.00 & 0.00 & 0.00 & 0.00 & 0.00 & 0.01 & 0.01 & 0.01 & 0.01 \\
\hline R-squared & 0.58 & 0.44 & 0.59 & 0.45 & 0.58 & 0.45 & 0.57 & 0.42 & 0.59 & 0.45 & 0.51 & 0.33 \\
\hline Observations & 798 & 798 & 798 & 798 & 798 & 798 & 798 & 798 & 798 & 798 & 798 & 798 \\
\hline F-test for NOF & $10.83^{* * *}$ & $10.83 * * *$ & $10.59 * * *$ & $10.59 * * *$ & $10.11^{* * *}$ & $10.11^{* * *}$ & $7.94^{* * *}$ & $7.94 * * *$ & $8.17^{* * *}$ & $8.17^{* * *}$ & $8.70 * * *$ & $8.70 * * *$ \\
\hline AP Chi-sq test for NOF & $72.05^{* * *}$ & $72.05^{* * *}$ & $57.26 * * *$ & $57.26 * * *$ & $58.01 * * *$ & $58.01 * * *$ & 16.34 & 16.34 & $67.81^{* * *}$ & $67.81^{* * *}$ & $34.12^{* * *}$ & $34.12 * * *$ \\
\hline F-test for interaction & $7.26^{* * *}$ & $7.26 * * *$ & $6.11^{* * *}$ & $6.11^{* * *}$ & $5.49 * * *$ & $5.49 * * *$ & $6.62^{* * *}$ & $6.62^{* * *}$ & $11.67^{* * *}$ & $11.67^{* * *}$ & $7.27^{* * *}$ & $7.27 * * *$ \\
\hline AP Chi-sq test for interaction & $84.39 * * *$ & $84.39 * * *$ & $57.74^{* * *}$ & $57.74^{* * *}$ & $52.86 * * *$ & $52.86^{* * *}$ & $26.39 * * *$ & $26.39 * * *$ & $143.88^{* * *}$ & $143.88^{* * *}$ & $55.76^{* * *}$ & $55.76^{* * *}$ \\
\hline \multirow{2}{*}{\multicolumn{13}{|c|}{$\begin{array}{l}\text { Robust standard errors in parentheses } \\
\text { We add } 1 \text { to the estimated coefficients on NOF in all NPFX regressions. } \\
* p<0.1, * * p<0.05, * * * p<0.01\end{array}$}} \\
\hline & & & & & & & & & & & & \\
\hline Implied effect on CA under high mobility & 0.11 & 0.03 & 0.20 & 0.15 & 0.21 & 0.15 & 0.41 & 0.41 & 0.08 & 0.00 & 0.14 & 0.07 \\
\hline Implied effect on CA under low mobility & 0.66 & 0.71 & 0.59 & 0.69 & 0.70 & 0.77 & 0.69 & 0.74 & 0.62 & 0.68 & 1.03 & 1.15 \\
\hline
\end{tabular}


Table 2b. Baseline Specification with Various Capital Mobility Measures and Preferred Set of Instruments (concluded)

\begin{tabular}{|c|c|c|c|c|c|c|c|c|c|c|c|c|}
\hline & Reg 1 & $\operatorname{Reg} 2$ & $\operatorname{Reg} 3$ & Reg 4 & Reg 5 & $\operatorname{Reg} 6$ & $\operatorname{Reg} 7$ & $\operatorname{Reg} 8$ & $\operatorname{Reg} 9$ & Reg 10 & Reg 11 & Reg 12 \\
\hline Dependent & CAX & NPFX & CAX & NPFX & CAX & NPFX & CAX & NPFX & CAX & NPFX & CAX & NPFX \\
\hline Mobility Measure & BOP share & BOP share & BOP fin. & BOP fin. & Bank assets & Bank assets & PC all & PC all & PC top & PC top & PC alt & PC alt \\
\hline \multirow[t]{2}{*}{ Lagged relative PPP GDP pc } & $-0.04 * * *$ & $-0.04 * * *$ & $-0.04 * * *$ & $-0.04 * * *$ & $-0.05^{* * *}$ & $-0.05^{* * *}$ & $-0.02^{* *}$ & -0.02 & $-0.02 *$ & -0.02 & $-0.03 * * *$ & $-0.03 * * *$ \\
\hline & 0.01 & 0.01 & 0.01 & 0.01 & 0.01 & 0.01 & 0.01 & 0.01 & 0.01 & 0.01 & 0.01 & 0.01 \\
\hline \multirow[t]{2}{*}{ Aging } & $2.63^{* * *}$ & $2.30 * * *$ & $2.77^{* * *}$ & $2.18^{* * *}$ & $2.81^{* * *}$ & $2.45^{* * *}$ & $2.58^{* * *}$ & $2.10^{* * *}$ & $2.49 * * *$ & $1.98^{* * *}$ & $2.83^{* * *}$ & $2.40^{* * *}$ \\
\hline & 0.5 & 0.55 & 0.56 & 0.61 & 0.51 & 0.57 & 0.54 & 0.57 & 0.52 & 0.56 & 0.49 & 0.52 \\
\hline \multirow[t]{2}{*}{ Lagged Growth } & -0.12 & $-0.20^{* *}$ & -0.04 & $-0.17^{*}$ & -0.04 & -0.12 & -0.11 & $-0.23 * * *$ & $-0.15^{*}$ & $-0.27^{* * *}$ & -0.1 & $-0.22^{* * *}$ \\
\hline & 0.08 & 0.09 & 0.08 & 0.09 & 0.09 & 0.1 & 0.08 & 0.08 & 0.07 & 0.08 & 0.07 & 0.08 \\
\hline \multirow[t]{2}{*}{ Energy } & $0.17^{* * *}$ & $0.15^{* * *}$ & $0.17^{* * *}$ & $0.15^{* * *}$ & $0.17^{* * *}$ & $0.15^{* * *}$ & $0.15^{* * *}$ & $0.12^{* * *}$ & $0.14^{* * *}$ & $0.11^{* * *}$ & $0.17^{* * *}$ & $0.15^{* * *}$ \\
\hline & 0.03 & 0.03 & 0.02 & 0.02 & 0.03 & 0.03 & 0.03 & 0.03 & 0.03 & 0.03 & 0.02 & 0.02 \\
\hline \multirow[t]{2}{*}{ Fiscal } & $0.26^{* * *}$ & $0.22^{* * *}$ & $0.35^{* * *}$ & $0.31^{* * *}$ & $0.31^{* * *}$ & $0.27^{* * *}$ & $0.30^{* * *}$ & $0.26^{* * *}$ & $0.30^{* * *}$ & $0.25^{* * *}$ & $0.32^{* * *}$ & $0.28^{* * *}$ \\
\hline & 0.06 & 0.06 & 0.06 & 0.06 & 0.06 & 0.06 & 0.06 & 0.06 & 0.06 & 0.06 & 0.06 & 0.06 \\
\hline \multirow[t]{2}{*}{ Net official flows (NOF) } & $0.36^{* * *}$ & $0.42^{* *}$ & $0.47^{* * *}$ & $0.57^{* * *}$ & $0.53^{* * *}$ & $0.57^{* * *}$ & $0.69^{* * *}$ & $0.79^{* * *}$ & $0.66^{* * *}$ & $0.78^{* * *}$ & $0.46^{* * *}$ & $0.51^{* * *}$ \\
\hline & 0.14 & 0.17 & 0.15 & 0.17 & 0.13 & 0.14 & 0.17 & 0.17 & 0.15 & 0.16 & 0.11 & 0.13 \\
\hline \multirow[t]{2}{*}{ Interaction with Mobility dummy } & 0.08 & 0 & $-0.27 *$ & $-0.39 * *$ & $-0.29 * *$ & $-0.39 * * *$ & $-0.59 * * *$ & $-0.76^{* * *}$ & $-0.56^{* * *}$ & $-0.74^{* * *}$ & $-0.21 *$ & $-0.30 * *$ \\
\hline & 0.16 & 0.19 & 0.14 & 0.19 & 0.13 & 0.15 & 0.15 & 0.16 & 0.13 & 0.15 & 0.12 & 0.15 \\
\hline \multirow[t]{2}{*}{ Lagged stock of official assets (NOA) } & $0.03^{* * *}$ & $0.03^{* *}$ & 0.01 & 0.01 & -0.01 & -0.02 & -0.01 & -0.02 & 0 & -0.01 & 0.02 & 0.03 \\
\hline & 0.01 & 0.01 & 0.02 & 0.02 & 0.02 & 0.02 & 0.02 & 0.02 & 0.02 & 0.02 & 0.02 & 0.02 \\
\hline \multirow[t]{2}{*}{ Interaction with Mobility dummy } & 0.01 & $0.02^{*}$ & $0.05^{* * *}$ & $0.05^{* * *}$ & $0.07^{* * *}$ & $0.08^{* * *}$ & $0.08^{* * *}$ & $0.09 * * *$ & $0.06 * * *$ & $0.08^{* * *}$ & $0.03^{*}$ & $0.04 *$ \\
\hline & 0.01 & 0.01 & 0.02 & 0.02 & 0.02 & 0.02 & 0.02 & 0.02 & 0.02 & 0.02 & 0.02 & 0.02 \\
\hline \multirow[t]{2}{*}{ Mobility } & $-0.01 * * *$ & $-0.01 * * *$ & -0.01 & -0.01 & 0 & $0.01 * *$ & -0.01 & -0.01 & $-0.01 * * *$ & $-0.01 * *$ & $-0.01^{* *}$ & $-0.01^{*}$ \\
\hline & 0 & 0 & 0 & 0 & 0 & 0 & 0.01 & 0.01 & 0 & 0 & 0.01 & 0.01 \\
\hline R-squared & 0.57 & 0.44 & 0.60 & 0.47 & 0.58 & 0.43 & 0.59 & 0.45 & 0.59 & 0.45 & 0.60 & 0.47 \\
\hline Observations & 798 & 798 & 798 & 798 & 798 & 798 & 798 & 798 & 798 & 798 & 798 & 798 \\
\hline F-test for NOF & $13.06 * * *$ & $13.06^{* * *}$ & $10.33^{* * *}$ & $10.33^{* * *}$ & $9.99 * * *$ & $9.99 * * *$ & $9.10^{* * *}$ & $9.10^{* * *}$ & $9.64^{* * *}$ & $9.64^{* * *}$ & $9.10^{* * *}$ & $9.10^{* * *}$ \\
\hline AP Chi-sq test for NOF & $82.47^{* * *}$ & $82.47^{* * *}$ & $58.35^{* * *}$ & $58.35^{* * *}$ & $78.15^{* * *}$ & $78.15^{* * *}$ & $56.55^{* * *}$ & $56.55^{* * *}$ & $61.09 * * *$ & $61.09 * * *$ & $56.55^{* * *}$ & $56.55^{* * *}$ \\
\hline F-test for interaction & $6.72 * * *$ & $6.72 * * *$ & $5.55^{* * *}$ & $5.55^{* * *}$ & $7.35^{* * *}$ & $7.35^{* * *}$ & $6.05^{* * *}$ & $6.05 * * *$ & $6.66^{* * *}$ & $6.66^{* * *}$ & $6.05^{* * *}$ & $6.05 * * *$ \\
\hline AP Chi-sq test for interaction & $29.71^{* * *}$ & $29.71 * * *$ & $40.60 * * *$ & $40.60 * * *$ & $73.83 * * *$ & $73.83 * * *$ & $67.31 * * *$ & $67.31 * * *$ & $75.14^{* * *}$ & $75.14 * * *$ & $67.31 * * *$ & $67.31 * * *$ \\
\hline \multirow{2}{*}{\multicolumn{13}{|c|}{$\begin{array}{l}\text { Robust standard errors in parentheses } \\
\text { We add } 1 \text { to the estimated coefficients on NOF in all NPFX regressions. } \\
* p<0.1, * * p<0.05, * * * p<0.01\end{array}$}} \\
\hline & & & & & & & & & & & & \\
\hline Implied effect on CA under high mobility & 0.44 & 0.42 & 0.20 & 0.18 & 0.24 & 0.18 & 0.10 & 0.03 & 0.10 & 0.04 & 0.25 & 0.21 \\
\hline Implied effect on CA under low mobility & 0.36 & 0.42 & 0.47 & 0.57 & 0.53 & 0.57 & 0.69 & 0.79 & 0.66 & 0.78 & 0.46 & 0.51 \\
\hline
\end{tabular}




\begin{tabular}{|c|c|c|c|c|c|c|c|c|c|c|c|c|}
\hline \multicolumn{13}{|c|}{ Table 3a. Regressions Including Various Mobility Measures without Instruments (continued) } \\
\hline & $\operatorname{Reg} 1$ & Reg 2 & $\operatorname{Reg} 3$ & $\operatorname{Reg} 4$ & $\operatorname{Reg} 5$ & $\operatorname{Reg} 6$ & $\operatorname{Reg} 7$ & $\operatorname{Reg} 8$ & $\operatorname{Reg} 9$ & $\operatorname{Reg} 10$ & $\operatorname{Reg} 11$ & $\operatorname{Reg} 12$ \\
\hline Dependent & CAX & NPFX & CAX & NPFX & CAX & NPFX & CAX & NPFX & CAX & NPFX & CAX & NPFX \\
\hline Mobility Measure & Chinn-Ito & Chinn-Ito & Schindler & Schindler & Quinn & Quinn & ICRG & ICRG & Reg. Qual. & Reg. Qual. & Rule of Law & Rule of Law \\
\hline \multirow[t]{2}{*}{ Lagged relative PPP GDP pc } & $-0.03^{\star * *}$ & $-0.04^{* * *}$ & $-0.04^{* \star *}$ & $-0.03^{* \star *}$ & $-0.02^{*}$ & $-0.02^{*}$ & $-0.04^{* * *}$ & $-0.04^{* * *}$ & 0.00 & 0.00 & -0.02 & -0.02 \\
\hline & 0.01 & 0.01 & 0.01 & 0.01 & 0.01 & 0.01 & 0.01 & 0.01 & 0.01 & 0.02 & 0.02 & 0.02 \\
\hline \multirow[t]{2}{*}{ Aging } & $2.29^{\star * \star}$ & $1.89^{\star * *}$ & $2.25^{\star * *}$ & $1.69^{* *}$ & $2.10^{* * *}$ & $1.68^{* \star}$ & $2.33^{\star * *}$ & $1.80^{\star *}$ & $1.32^{* *}$ & 0.82 & $2.19^{\star \star *}$ & $1.73^{\star *}$ \\
\hline & 0.61 & 0.67 & 0.63 & 0.7 & 0.61 & 0.65 & 0.63 & 0.73 & 0.63 & 0.71 & 0.61 & 0.7 \\
\hline \multirow[t]{2}{*}{ Lagged Growth } & -0.03 & -0.15 & -0.05 & $-0.20^{* *}$ & -0.08 & $-0.22^{* *}$ & 0 & -0.12 & -0.02 & -0.16 & 0 & -0.14 \\
\hline & 0.09 & 0.1 & 0.09 & 0.1 & 0.09 & 0.1 & 0.09 & 0.1 & 0.09 & 0.1 & 0.09 & 0.1 \\
\hline \multirow[t]{2}{*}{ Energy } & $0.24^{\star * *}$ & $0.19^{* * *}$ & $0.24^{* * *}$ & $0.19^{\star \star *}$ & $0.24^{\star * *}$ & $0.19^{* * *}$ & $0.24^{* * *}$ & $0.20^{* * *}$ & $0.21^{* * *}$ & $0.16^{\star * *}$ & $0.23^{\star \star *}$ & $0.19^{* * *}$ \\
\hline & 0.03 & 0.03 & 0.03 & 0.03 & 0.03 & 0.03 & 0.02 & 0.03 & 0.03 & 0.03 & 0.03 & 0.03 \\
\hline \multirow[t]{2}{*}{ Fiscal } & $0.19^{\star * *}$ & $0.16^{\star * *}$ & $0.18^{* * *}$ & $0.15^{\star * *}$ & $0.18^{* * *}$ & $0.16^{* * *}$ & $0.18^{* * *}$ & $0.15^{\star * *}$ & $0.19^{* * *}$ & $0.16^{\star * *}$ & $0.18^{* * *}$ & $0.15^{\star *}$ \\
\hline & 0.05 & 0.06 & 0.05 & 0.06 & 0.05 & 0.06 & 0.05 & 0.06 & 0.05 & 0.06 & 0.05 & 0.06 \\
\hline \multirow[t]{2}{*}{ Net official flows (NOF) } & $0.29^{\star * *}$ & $0.35^{\star * *}$ & $0.30^{* * *}$ & $0.35^{\star \star *}$ & $0.29^{* * *}$ & $0.37^{\star * *}$ & $0.18^{* * *}$ & $0.24^{* * *}$ & $0.30^{* * *}$ & $0.35^{\star * *}$ & $0.28^{* * *}$ & $0.32^{\star * *}$ \\
\hline & 0.05 & 0.06 & 0.05 & 0.06 & 0.05 & 0.06 & 0.06 & 0.08 & 0.05 & 0.07 & 0.05 & 0.07 \\
\hline \multirow[t]{2}{*}{ Interaction with Mobility dummy } & $-0.18^{\star * *}$ & $-0.19^{* *}$ & $-0.18^{\star * *}$ & $-0.18^{* *}$ & $-0.18^{\star * *}$ & $-0.22^{\star * *}$ & 0.02 & 0.01 & $-0.17^{* \star *}$ & $-0.17^{\star *}$ & $-0.12^{* *}$ & -0.11 \\
\hline & 0.06 & 0.08 & 0.06 & 0.08 & 0.06 & 0.08 & 0.07 & 0.09 & 0.06 & 0.08 & 0.06 & 0.08 \\
\hline \multirow[t]{2}{*}{ Lagged stock of official assets (NOA) } & $0.04^{* *}$ & $0.04^{* *}$ & $0.05^{\star * *}$ & $0.05^{\star * *}$ & $0.03^{* *}$ & $0.04^{* *}$ & 0 & -0.01 & $0.03^{\star *}$ & $0.04^{* *}$ & $0.04^{* *}$ & $0.04^{* *}$ \\
\hline & 0.02 & 0.02 & 0.02 & 0.02 & 0.02 & 0.02 & 0.02 & 0.02 & 0.02 & 0.02 & 0.02 & 0.02 \\
\hline \multirow[t]{2}{*}{ Interaction with Mobility dummy } & $0.03^{*}$ & 0.03 & 0.02 & 0.01 & $0.03^{*}$ & 0.03 & $0.06^{* * *}$ & $0.07^{* * *}$ & $0.03^{*}$ & 0.03 & 0.02 & 0.02 \\
\hline & 0.02 & 0.02 & 0.02 & 0.02 & 0.02 & 0.02 & 0.02 & 0.02 & 0.02 & 0.02 & 0.02 & 0.02 \\
\hline \multirow[t]{2}{*}{ Mobility } & -0.01 & 0 & 0 & -0.01 & $-0.03^{* * *}$ & $-0.03^{\star \star *}$ & 0 & 0.01 & $-0.06^{* \star *}$ & $-0.06^{\star * *}$ & -0.02 & -0.02 \\
\hline & 0.01 & 0.01 & 0.01 & 0.01 & 0.01 & 0.01 & 0.01 & 0.01 & 0.02 & 0.02 & 0.02 & 0.02 \\
\hline R-squared & 0.55 & 0.52 & 0.55 & 0.52 & 0.56 & 0.52 & 0.54 & 0.52 & 0.56 & 0.52 & 0.54 & 0.52 \\
\hline Observations & 803 & 803 & 803 & 803 & 803 & 803 & 803 & 803 & 803 & 803 & 803 & 803 \\
\hline \multicolumn{13}{|l|}{ Robust standard errors in parentheses } \\
\hline \multirow{2}{*}{\multicolumn{13}{|c|}{$\begin{array}{l}\text { We add } 1 \text { to the estimated coefficients on NOF in all NPFX regressions. } \\
{ }^{*} p<0.1,{ }^{* *} p<0.05,{ }^{* * *} p<0.01\end{array}$}} \\
\hline & & & & & & & & & & & & \\
\hline Implied effect on CA under high mobility & 0.11 & 0.16 & 0.12 & 0.17 & 0.11 & 0.15 & 0.20 & 0.25 & 0.13 & 0.18 & 0.16 & 0.21 \\
\hline Implied effect on CA under low mobility & 0.29 & 0.35 & 0.30 & 0.35 & 0.29 & 0.37 & 0.18 & 0.24 & 0.30 & 0.35 & 0.28 & 0.32 \\
\hline
\end{tabular}




\begin{tabular}{|c|c|c|c|c|c|c|c|c|c|c|c|c|}
\hline & Reg 1 & $\operatorname{Reg} 2$ & $\operatorname{Reg} 3$ & $\operatorname{Reg} 4$ & $\operatorname{Reg} 5$ & $\operatorname{Reg} 6$ & $\operatorname{Reg} 7$ & $\operatorname{Reg} 8$ & $\operatorname{Reg} 9$ & $\operatorname{Reg} 10$ & Reg 11 & $\operatorname{Reg} 12$ \\
\hline Dependent & CAX & NPFX & CAX & NPFX & CAX & NPFX & CAX & NPFX & CAX & NPFX & CAX & NPFX \\
\hline Mobility Measure & BOP share & BOP share & BOP fin. & BOP fin. & Bank assets & Bank assets & PC all & PC all & PC top & PC top & PC alt & PC alt \\
\hline \multirow[t]{2}{*}{ Lagged relative PPP GDP pc } & $-0.03 * * *$ & $-0.03^{* *}$ & $-0.03 * * *$ & $-0.03 * * *$ & $-0.04^{* * *}$ & $-0.04 * * *$ & 0.02 & 0.02 & 0.01 & 0.01 & -0.01 & -0.01 \\
\hline & 0.01 & 0.01 & 0.01 & 0.01 & 0.01 & 0.01 & 0.02 & 0.02 & 0.01 & 0.01 & 0.01 & 0.01 \\
\hline \multirow[t]{2}{*}{ Aging } & $1.96^{* * *}$ & $1.50^{* *}$ & $1.75^{* * *}$ & $1.37 * *$ & $2.49 * * *$ & $1.99 * *$ & $1.98^{* * *}$ & $1.52^{* *}$ & $1.27^{* *}$ & 0.8 & $2.20^{* * *}$ & $1.78^{* * *}$ \\
\hline & 0.56 & 0.64 & 0.57 & 0.65 & 0.71 & 0.79 & 0.58 & 0.63 & 0.63 & 0.67 & 0.57 & 0.62 \\
\hline \multirow[t]{2}{*}{ Lagged Growth } & -0.02 & -0.13 & -0.04 & $-0.16^{*}$ & -0.03 & -0.16 & -0.05 & $-0.18^{*}$ & -0.07 & $-0.21^{* *}$ & -0.05 & $-0.18^{* *}$ \\
\hline & 0.09 & 0.09 & 0.08 & 0.09 & 0.09 & 0.1 & 0.09 & 0.1 & 0.09 & 0.1 & 0.08 & 0.08 \\
\hline \multirow[t]{2}{*}{ Energy } & $0.24^{* * *}$ & $0.20^{* * *}$ & $0.23^{* * *}$ & $0.18^{* * *}$ & $0.26^{* * *}$ & $0.22^{* * *}$ & $0.22 * * *$ & $0.17^{* * *}$ & $0.22^{* * *}$ & $0.16^{* * *}$ & $0.25^{* * *}$ & $0.21 * * *$ \\
\hline & 0.03 & 0.03 & 0.02 & 0.03 & 0.03 & 0.03 & 0.03 & 0.03 & 0.03 & 0.03 & 0.02 & 0.03 \\
\hline \multirow[t]{2}{*}{ Fiscal } & $0.16^{* * *}$ & $0.12^{* *}$ & $0.21^{* * *}$ & $0.18^{* * *}$ & $0.19 * * *$ & $0.16^{* * *}$ & $0.14^{* * *}$ & $0.11^{*}$ & $0.17^{* * *}$ & $0.14^{* * *}$ & $0.15^{* * *}$ & $0.12^{* *}$ \\
\hline & 0.05 & 0.06 & 0.05 & 0.06 & 0.05 & 0.06 & 0.05 & 0.06 & 0.05 & 0.05 & 0.05 & 0.05 \\
\hline \multirow[t]{2}{*}{ Net official flows (NOF) } & $0.28^{* * *}$ & $0.39 * * *$ & $0.34^{* * *}$ & $0.44^{* * *}$ & $0.18^{* * *}$ & $0.23^{* * *}$ & $0.31 * * *$ & $0.40^{* * *}$ & $0.31^{* * *}$ & $0.40^{* * *}$ & $0.35^{* * *}$ & $0.48 * * *$ \\
\hline & 0.05 & 0.06 & 0.05 & 0.06 & 0.05 & 0.08 & 0.05 & 0.06 & 0.05 & 0.06 & 0.05 & 0.06 \\
\hline \multirow[t]{2}{*}{ Interaction with Mobility dummy } & $-0.11 *$ & $-0.18 * * *$ & $-0.21 * * *$ & $-0.28 * * *$ & 0.01 & 0.02 & $-0.19 * * *$ & $-0.25 * * *$ & $-0.21 * * *$ & $-0.27 * * *$ & $-0.23 * * *$ & $-0.33^{* * *}$ \\
\hline & 0.05 & 0.06 & 0.06 & 0.07 & 0.06 & 0.09 & 0.06 & 0.08 & 0.06 & 0.08 & 0.06 & 0.07 \\
\hline \multirow[t]{2}{*}{ Lagged stock of official assets (NOA) } & $0.04^{* * *}$ & $0.04^{* * *}$ & $0.04^{* * *}$ & $0.03^{* *}$ & 0.03 & 0.03 & $0.04 * *$ & $0.04 * *$ & $0.03^{*}$ & $0.03 *$ & $0.06^{* * *}$ & $0.06 * * *$ \\
\hline & 0.01 & 0.01 & 0.01 & 0.01 & 0.02 & 0.02 & 0.02 & 0.02 & 0.02 & 0.02 & 0.02 & 0.02 \\
\hline \multirow[t]{2}{*}{ Interaction with Mobility dummy } & $0.02 *$ & $0.02 * *$ & $0.03^{* *}$ & $0.04^{* * *}$ & $0.04^{* *}$ & 0.03 & 0.02 & 0.02 & $0.04 * *$ & $0.04^{* *}$ & 0 & 0.01 \\
\hline & 0.01 & 0.01 & 0.01 & 0.01 & 0.02 & 0.02 & 0.02 & 0.02 & 0.02 & 0.02 & 0.02 & 0.02 \\
\hline \multirow[t]{2}{*}{ Mobility } & $-0.04 * * *$ & $-0.05 * * *$ & $-0.16^{* *}$ & $-0.15^{*}$ & 0 & 0 & $-0.07 * * *$ & $-0.07^{* * *}$ & $-0.09 * * *$ & $-0.09 * * *$ & $-0.05^{* * *}$ & $-0.04 * * *$ \\
\hline & 0.01 & 0.01 & 0.07 & 0.08 & 0.01 & 0.01 & 0.02 & 0.02 & 0.02 & 0.02 & 0.01 & 0.01 \\
\hline R-squared & 0.55 & 0.54 & 0.56 & 0.53 & 0.54 & 0.51 & 0.56 & 0.53 & 0.56 & 0.54 & 0.57 & 0.55 \\
\hline Observations & 803 & 803 & 803 & 803 & 803 & 803 & 803 & 803 & 803 & 803 & 803 & 803 \\
\hline \multirow{2}{*}{\multicolumn{13}{|c|}{$\begin{array}{l}\text { Robust standard errors in parentheses } \\
\text { We add } 1 \text { to the estimated coefficients on NOF in all NPFX regressions. } \\
{ }^{*} p<0.1,{ }^{* *} p<0.05, * * * p<0.01\end{array}$}} \\
\hline & & & & & & & & & & & & \\
\hline Implied effect on CA under high mobility & 0.17 & 0.21 & 0.13 & 0.16 & 0.19 & 0.25 & 0.12 & 0.15 & 0.10 & 0.13 & 0.12 & 0.15 \\
\hline Implied effect on CA under low mobility & 0.28 & 0.39 & 0.34 & 0.44 & 0.18 & 0.23 & 0.31 & 0.40 & 0.31 & 0.40 & 0.35 & 0.48 \\
\hline
\end{tabular}




\begin{tabular}{|c|c|c|c|c|c|c|c|c|c|c|c|c|}
\hline & Reg 1 & Reg 2 & Reg 3 & $\operatorname{Reg} 4$ & Reg 5 & $\operatorname{Reg} 6$ & $\operatorname{Reg} 7$ & $\operatorname{Reg} 8$ & $\operatorname{Reg} 9$ & Reg 10 & Reg 11 & Reg 12 \\
\hline Dependent & CAX & NPFX & CAX & NPFX & CAX & NPFX & CAX & NPFX & CAX & NPFX & CAX & NPFX \\
\hline Mobility Measure & Chinn-Ito & Chinn-Ito & Schindler & Schindler & Quinn & Quinn & ICRG & ICRG & Reg. Qual. & Reg. Qual. & Rule of Law & Rule of Law \\
\hline \multirow[t]{2}{*}{ Lagged relative PPP GDP pc } & $-0.05^{* * *}$ & $-0.05^{* * *}$ & $-0.04^{* * *}$ & $-0.04 * * *$ & $-0.04^{* * *}$ & $-0.04^{* * *}$ & $-0.05^{* * *}$ & $-0.06^{* * *}$ & $-0.03 * * *$ & $-0.03 * * *$ & $-0.05^{* * *}$ & $-0.05^{* * *}$ \\
\hline & 0.01 & 0.01 & 0.01 & 0.01 & 0.01 & 0.01 & 0.01 & 0.01 & 0.01 & 0.01 & 0.01 & 0.01 \\
\hline \multirow[t]{2}{*}{ Aging } & $2.68^{* * *}$ & $2.17^{* * *}$ & $2.62^{* * *}$ & $2.22^{* * *}$ & $2.55^{* * *}$ & $2.07^{* * *}$ & $3.01^{* * *}$ & $2.69^{* * *}$ & $3.16^{* * *}$ & $2.66^{* * *}$ & $2.91^{* * *}$ & $2.36^{* * *}$ \\
\hline & 0.39 & 0.58 & 0.55 & 0.57 & 0.53 & 0.55 & 0.51 & 0.55 & 0.51 & 0.55 & 0.54 & 0.57 \\
\hline \multirow[t]{2}{*}{ Lagged Growth } & $-0.12^{*}$ & $-0.24^{* * *}$ & -0.13 & $-0.25^{* * *}$ & -0.13 & $-0.24^{* * *}$ & -0.04 & -0.13 & -0.05 & $-0.18^{* *}$ & -0.04 & $-0.18^{* *}$ \\
\hline & 0.06 & 0.08 & 0.08 & 0.08 & 0.08 & 0.08 & 0.08 & 0.09 & 0.07 & 0.08 & 0.08 & 0.08 \\
\hline \multirow[t]{2}{*}{ Energy } & $0.17^{* * *}$ & $0.14^{* * *}$ & $0.17^{* * *}$ & $0.14^{* * *}$ & $0.16^{* * *}$ & $0.13^{* * *}$ & $0.19^{* * *}$ & $0.17^{* * *}$ & $0.17^{* * *}$ & $0.14^{* * *}$ & $0.18^{* * *}$ & $0.15^{* * *}$ \\
\hline & 0.02 & 0.03 & 0.02 & 0.03 & 0.02 & 0.03 & 0.02 & 0.02 & 0.02 & 0.02 & 0.02 & 0.03 \\
\hline \multirow[t]{2}{*}{ Fiscal } & $0.35^{* * *}$ & $0.30^{* * *}$ & $0.32^{* * *}$ & $0.28^{* * *}$ & $0.32^{* * *}$ & $0.28^{* * *}$ & $0.33^{* * *}$ & $0.30^{* * *}$ & $0.35^{* * *}$ & $0.31^{* * *}$ & $0.31^{* * *}$ & $0.27^{* * *}$ \\
\hline & 0.04 & 0.06 & 0.06 & 0.06 & 0.06 & 0.06 & 0.06 & 0.06 & 0.06 & 0.06 & 0.06 & 0.06 \\
\hline \multirow[t]{2}{*}{ Net official flows (NOF) } & $0.44^{* * *}$ & $0.54^{* * *}$ & $0.50^{* * *}$ & $0.58^{* * *}$ & $0.55^{* * *}$ & $0.62^{* * *}$ & $0.51^{*}$ & $0.50^{*}$ & $0.31^{* *}$ & $0.42^{* * *}$ & $0.49 * * *$ & $0.59^{* * *}$ \\
\hline & 0.09 & 0.13 & 0.12 & 0.13 & 0.11 & 0.11 & 0.27 & 0.29 & 0.13 & 0.14 & 0.13 & 0.14 \\
\hline \multirow[t]{2}{*}{ Interaction with Mobility dummy } & $-0.33^{* * *}$ & $-0.50 * * *$ & $-0.41 * * *$ & $-0.57 * * *$ & $-0.44^{* * *}$ & $-0.58 * * *$ & -0.3 & -0.32 & -0.17 & $-0.37 * * *$ & $-0.26^{* *}$ & $-0.45^{* * *}$ \\
\hline & 0.1 & 0.12 & 0.12 & 0.13 & 0.11 & 0.12 & 0.28 & 0.3 & 0.14 & 0.14 & 0.13 & 0.13 \\
\hline \multirow[t]{2}{*}{ Lagged stock of official assets (NOA) } & $0.03^{* *}$ & 0.03 & 0.02 & 0.02 & 0.01 & 0.01 & 0 & 0.02 & 0.02 & 0.02 & 0 & 0 \\
\hline & 0.01 & 0.02 & 0.02 & 0.02 & 0.02 & 0.02 & 0.02 & 0.02 & 0.02 & 0.02 & 0.02 & 0.02 \\
\hline \multirow[t]{2}{*}{ Interaction with Mobility dummy } & $0.04^{* * *}$ & $0.04 * *$ & $0.05^{* *}$ & $0.05^{* * *}$ & $0.05^{* * *}$ & $0.06^{* * *}$ & $0.06^{* * *}$ & $0.05^{* * *}$ & $0.04 * *$ & $0.05^{* * *}$ & $0.07^{* * *}$ & $0.07^{* * *}$ \\
\hline & 0.01 & 0.02 & 0.02 & 0.02 & 0.02 & 0.02 & 0.02 & 0.02 & 0.02 & 0.02 & 0.02 & 0.02 \\
\hline \multirow[t]{2}{*}{ Mobility } & $0.01^{*}$ & $0.01^{*}$ & $-0.01 *$ & 0.00 & 0.00 & 0.00 & 0.00 & 0.00 & $-0.02^{* * *}$ & $-0.02 * * *$ & 0 & 0 \\
\hline & 0.00 & 0.00 & 0.00 & 0.00 & 0.00 & 0.00 & 0.00 & 0.00 & 0 & 0 & 0 & 0 \\
\hline R-squared & 0.60 & 0.46 & 0.60 & 0.46 & 0.60 & 0.46 & 0.59 & 0.43 & 0.61 & 0.46 & 0.60 & 0.45 \\
\hline Observations & 801 & 801 & 801 & 801 & 801 & 801 & 801 & 801 & 801 & 801 & 801 & 801 \\
\hline F-test for NOF & $7.66^{* * *}$ & $7.66^{* * *}$ & $7.76^{* * *}$ & $7.76^{* * *}$ & $7.50 * * *$ & $7.50^{* * *}$ & $7.51^{* * *}$ & $7.51^{* * *}$ & $7.01^{* * *}$ & $7.01^{* * *}$ & $7.10^{* * *}$ & $7.10^{* * *}$ \\
\hline AP Chi-sq test for NOF & $549.12^{* * *}$ & $549.12^{* * *}$ & $584.74 * * *$ & $584.74^{* * *}$ & $528.70 * * *$ & $528.70^{* * *}$ & $142.63^{* * *}$ & $142.63^{* * *}$ & $525.89 * * *$ & $525.89 * * *$ & $212.94 * * *$ & $212.94^{* * *}$ \\
\hline F-test for interaction & $2.67^{* * *}$ & $2.67^{* * *}$ & $2.06^{* * *}$ & $2.06^{* * *}$ & $2.49 * * *$ & $2.49 * * *$ & $9.39 * * *$ & $9.39 * * *$ & $2.26 * * *$ & $2.26^{* * *}$ & $81.21^{* * *}$ & $81.21 * * *$ \\
\hline AP Chi-sq test for interaction & $204.80^{* * *}$ & $204.80^{* * *}$ & $160.57^{* * *}$ & $160.57^{* * *}$ & $190.39^{* * *}$ & $190.39 * * *$ & $426.68^{* * *}$ & $426.68^{* * *}$ & $174.55^{* * *}$ & $174.55^{* * *}$ & $6062.20^{* * *}$ & $6062.20^{* * *}$ \\
\hline \multirow{2}{*}{\multicolumn{13}{|c|}{$\begin{array}{l}\text { Robust standard errors in parentheses } \\
\text { We add } 1 \text { to the estimated coefficients on NOF in all NPFX regressions. } \\
{ }^{*} p<0.1,{ }^{* *} p<0.05,{ }^{* * *} p<0.01\end{array}$}} \\
\hline & & & & & & & & & & & & \\
\hline Implied effect on CA under high mobility & 0.11 & 0.04 & 0.09 & 0.01 & 0.11 & 0.04 & 0.21 & 0.18 & 0.14 & 0.05 & 0.23 & 0.14 \\
\hline Implied effect on CA under low mobility & 0.44 & 0.54 & 0.50 & 0.58 & 0.55 & 0.62 & 0.51 & 0.50 & 0.31 & 0.42 & 0.49 & 0.59 \\
\hline
\end{tabular}




\begin{tabular}{|c|c|c|c|c|c|c|c|c|c|c|c|c|}
\hline & Reg 1 & Reg 2 & Reg 3 & Reg 4 & Reg 5 & Reg 6 & $\operatorname{Reg} 7$ & Reg 8 & Reg 9 & Reg 10 & Reg 11 & Reg 12 \\
\hline Dependent & CAX & NPFX & CAX & NPFX & CAX & NPFX & CAX & NPFX & CAX & NPFX & CAX & NPFX \\
\hline Mobility Measure & BOP share & BOP share & BOP fin. & BOP fin. & Bank assets & Bank assets & PC all & PC all & PC top & PC top & PC alt & PC alt \\
\hline \multirow[t]{2}{*}{ Lagged relative PPP GDP pc } & $-0.04^{* * *}$ & $-0.04^{* * *}$ & $-0.04^{* * *}$ & $-0.04^{* * *}$ & $-0.05^{* * *}$ & $-0.06^{* * *}$ & $-0.03^{* *}$ & $-0.02^{* *}$ & $-0.03^{* *}$ & $-0.02^{* *}$ & $-0.03^{* * *}$ & $-0.03^{* * *}$ \\
\hline & 0.01 & 0.01 & 0.01 & 0.01 & 0.01 & 0.01 & 0.01 & 0.01 & 0.01 & 0.01 & 0.01 & 0.01 \\
\hline \multirow[t]{2}{*}{ Aging } & $2.93^{* * *}$ & $2.63^{* * *}$ & $2.68^{* * *}$ & $2.21^{* * *}$ & $2.99 * * *$ & $2.60^{* * *}$ & $2.85^{* * *}$ & $2.40^{* * *}$ & $2.79 * * *$ & $2.31^{* * *}$ & $3.08^{* * *}$ & $2.65^{* * *}$ \\
\hline & 0.51 & 0.54 & 0.56 & 0.61 & 0.51 & 0.56 & 0.55 & 0.58 & 0.54 & 0.57 & 0.52 & 0.55 \\
\hline \multirow[t]{2}{*}{ Lagged Growth } & -0.06 & -0.13 & -0.07 & $-0.17^{*}$ & -0.04 & -0.13 & -0.07 & $-0.19 * *$ & -0.1 & $-0.22^{* * *}$ & -0.09 & $-0.22 * * *$ \\
\hline & 0.08 & 0.09 & 0.08 & 0.09 & 0.08 & 0.09 & 0.08 & 0.08 & 0.08 & 0.08 & 0.08 & 0.08 \\
\hline \multirow[t]{2}{*}{ Energy } & $0.19 * * *$ & $0.17^{* * *}$ & $0.17^{* * *}$ & $0.15^{* * *}$ & $0.19 * * *$ & $0.17^{* * *}$ & $0.16^{* * *}$ & $0.13^{* * *}$ & $0.16^{* * *}$ & $0.13^{* * *}$ & $0.19 * * *$ & $0.17^{* * *}$ \\
\hline & 0.02 & 0.02 & 0.02 & 0.02 & 0.03 & 0.03 & 0.02 & 0.03 & 0.02 & 0.03 & 0.02 & 0.02 \\
\hline \multirow[t]{2}{*}{ Fiscal } & $0.32^{* * *}$ & $0.28^{* * *}$ & $0.37^{* * *}$ & $0.33^{* * *}$ & $0.33^{* * *}$ & $0.29 * * *$ & $0.33^{* * *}$ & $0.28^{* * *}$ & $0.33^{* * *}$ & $0.28^{* * *}$ & $0.37^{* * *}$ & $0.34^{* * *}$ \\
\hline & 0.06 & 0.06 & 0.06 & 0.06 & 0.06 & 0.06 & 0.06 & 0.06 & 0.06 & 0.06 & 0.06 & 0.06 \\
\hline \multirow[t]{2}{*}{ Net official flows (NOF) } & $0.42^{* * *}$ & $0.46^{* * *}$ & $0.58^{* * *}$ & $0.56^{* * *}$ & $0.38^{* * *}$ & $0.43^{* * *}$ & $0.51^{* * *}$ & $0.60^{* * *}$ & $0.47^{* * *}$ & $0.58^{* * *}$ & $0.38^{* * *}$ & $0.47^{* * *}$ \\
\hline & 0.13 & 0.15 & 0.12 & 0.14 & 0.1 & 0.11 & 0.13 & 0.13 & 0.13 & 0.13 & 0.12 & 0.12 \\
\hline \multirow[t]{2}{*}{ Interaction with Mobility dummy } & $-0.27^{* *}$ & $-0.35^{* *}$ & $-0.45^{* * *}$ & $-0.49 * * *$ & -0.16 & $-0.24^{* *}$ & $-0.39 * * *$ & $-0.55^{* * *}$ & $-0.38^{* * *}$ & $-0.56 * * *$ & $-0.30 * * *$ & $-0.47^{* * *}$ \\
\hline & 0.13 & 0.16 & 0.14 & 0.17 & 0.11 & 0.12 & 0.12 & 0.12 & 0.12 & 0.13 & 0.11 & 0.12 \\
\hline \multirow[t]{2}{*}{ Lagged stock of official assets (NOA) } & $0.04^{* * *}$ & $0.04^{* * *}$ & 0 & 0.02 & -0.01 & -0.01 & 0 & 0 & 0.02 & 0.01 & 0.03 & 0.03 \\
\hline & 0.01 & 0.01 & 0.02 & 0.02 & 0.02 & 0.02 & 0.02 & 0.02 & 0.02 & 0.02 & 0.02 & 0.02 \\
\hline \multirow[t]{2}{*}{ Interaction with Mobility dummy } & $0.02^{*}$ & $0.03^{* *}$ & $0.06 * * *$ & $0.05^{* * *}$ & $0.07^{* * *}$ & $0.07^{* * *}$ & $0.06^{* * *}$ & $0.07^{* * *}$ & $0.05^{* * *}$ & $0.06^{* * *}$ & $0.03^{*}$ & $0.04^{* *}$ \\
\hline & 0.01 & 0.01 & 0.02 & 0.02 & 0.02 & 0.02 & 0.02 & 0.02 & 0.02 & 0.02 & 0.02 & 0.02 \\
\hline \multirow[t]{2}{*}{ Mobility } & $-0.01^{* *}$ & $-0.01 * *$ & 0 & -0.01 & 0 & $0.01 * *$ & $-0.01 *$ & $-0.01 * *$ & $-0.01 * * *$ & $-0.01 * * *$ & $-0.01^{* *}$ & $-0.01^{* *}$ \\
\hline & 0 & 0 & 0 & 0 & 0 & 0 & 0.01 & 0.01 & 0 & 0 & 0.01 & 0.01 \\
\hline R-squared & 0.59 & 0.45 & 0.60 & 0.46 & 0.59 & 0.44 & 0.61 & 0.47 & 0.61 & 0.47 & 0.61 & 0.47 \\
\hline Observations & 801 & 801 & 801 & 801 & 801 & 801 & 801 & 801 & 801 & 801 & 801 & 801 \\
\hline F-test for NOF & $7.45^{* * *}$ & $7.45^{* * *}$ & $7.38^{* * *}$ & $7.38^{* * *}$ & $8.06^{* * *}$ & $8.06 * * *$ & $7.23^{* * *}$ & $7.23 * * *$ & $7.37^{* * *}$ & $7.37^{* * *}$ & $8.23 * * *$ & $8.23 * * *$ \\
\hline AP Chi-sq test for NOF & $554.86^{* * *}$ & $554.86^{* * *}$ & $574.88^{* * *}$ & $574.88^{* * *}$ & $496.95^{* * *}$ & $496.95^{* * *}$ & $2.33^{* * *}$ & $2.33^{* * *}$ & $519.96^{* * *}$ & $519.96^{* * *}$ & $520.00 * * *$ & $520.00 * * *$ \\
\hline F-test for interaction & $2.78^{* * *}$ & $2.78^{* * *}$ & $4.91^{* * *}$ & $4.91^{* * *}$ & $3.23^{* * *}$ & $3.23^{* * *}$ & $513.93 * * *$ & $513.93 * * *$ & $2.39 * * *$ & $2.39 * * *$ & $3.41^{* * *}$ & $3.41^{* * *}$ \\
\hline AP Chi-sq test for interaction & $205.23^{* * *}$ & $205.23 * * *$ & $379.82 * * *$ & $379.82^{* * *}$ & $227.35^{* * *}$ & $227.35^{* * *}$ & $179.39 * * *$ & $179.39 * * *$ & $184.90^{* * *}$ & $184.90^{* * *}$ & $176^{* * *}$ & $176^{* * *}$ \\
\hline \multirow{2}{*}{\multicolumn{13}{|c|}{$\begin{array}{l}\text { Robust standard errors in parentheses } \\
\text { We add } 1 \text { to the estimated coefficients on NOF in all NPFX regressions. } \\
{ }^{*} p<0.1,{ }^{* *} p<0.05,{ }^{* * *} p<0.01\end{array}$}} \\
\hline & & & & & & & & & & & & \\
\hline Implied effect on CA under high mobility & 0.15 & 0.11 & 0.13 & 0.07 & 0.22 & 0.19 & 0.12 & 0.05 & 0.09 & 0.02 & 0.08 & 0.00 \\
\hline Implied effect on CA under low mobility & 0.42 & 0.46 & 0.58 & 0.56 & 0.38 & 0.43 & 0.51 & 0.60 & 0.47 & 0.58 & 0.38 & 0.47 \\
\hline
\end{tabular}




\begin{tabular}{|c|c|c|c|c|c|c|c|c|c|c|c|c|c|c|c|c|c|c|c|c|c|c|c|c|}
\hline & & Tab & le 5. & Rok & oust & ness & $5 \mathrm{Cn}$ & eck & $5 \mathrm{WI}$ & $n 6$ & & IV! & sul & re c & Ca & Jit & IVIC & UII & & & & & & \\
\hline & Reg 1 & $\begin{array}{ll}\operatorname{Reg} 2 \\
\end{array}$ & 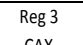 & $\begin{array}{l}\operatorname{Reg} 4 \\
\end{array}$ & $\begin{array}{l}\operatorname{Reg} 5 \\
\end{array}$ & 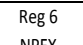 & $\begin{array}{l}\operatorname{Reg} 7 \\
\end{array}$ & Reg 8 & Reg 9 & $\begin{array}{l}\text { Reg } 10 \\
\text { nepry }\end{array}$ & Reg 11 & Reg 12 & Reg 13 & Reg 14 & Reg 15 & Reg 16 & Reg 17 & Reg 18 & Reg 19 & $\operatorname{Reg} 20$ & $\operatorname{Reg} 21$ & $\operatorname{Reg} 22$ & $\operatorname{Reg} 23$ & Reg 24 \\
\hline Dependent & CAX & NPFX & CAX & NPFX & CAX & NPFX & CAX & NPFX & CAX & NPFX & CAX & NPFX & CAX & NPFX & CAX & NPFX & CAX & NPFX & CAX & NPFX & CAX & NPFX & CAX & NPFX \\
\hline Mobility Measure & Quinn & Quinn & Quinn & Quinn & Quinn & Quinn & Quinn & Quinn & Quinn & Quinn & Quinn & Quinn & Quinn & Quinn & Quinn & Quinn & Quinn & Quinn & Quinn & Quinn & Quinn & Quinn & Quinn & Quinn \\
\hline $\begin{array}{l}\text { Lagged relative PPP GDP pc } \\
\text {. }\end{array}$ & $-0.04^{* * *}$ & $-0.04^{* * *}$ & $-0.09^{* * *}$ & $-0.09^{* * *}$ & $-0.04^{* * *}$ & $-0.04^{* * *}$ & -0.07 & -0.03 & $-0.07^{* *}$ & $-0.08^{* *}$ & 0 & 0.01 & $-0.02^{*}$ & $-0.03^{*}$ & $-0.04^{* * *}$ & $-0.03^{* * *}$ & $-0.04^{* * *}$ & $-0.04^{* * *}$ & -0.01 & -0.01 & $-0.03^{* * *}$ & $-0.03^{* * *}$ & $-0.06^{* * *}$ & $-0.06^{* * *}$ \\
\hline Interaction with Mobility dummy & 0.01 & 0.01 & 0.01 & 0.01 & 0.01 & 0.01 & 0.05 & 0.05 & 0.03 & 0.03 & 0.02 & 0.02 & 0.01 & 0.01 & 0.01 & 0.01 & 0.01 & 0.01 & 0.01 & 0.01 & 0.01 & 0.01 & $\begin{array}{c}0.01 \\
0.04^{* * *}\end{array}$ & $\begin{array}{c}0.01 \\
0.03^{* *}\end{array}$ \\
\hline & & & & & & & & & & & & & & & & & & & & & & & 0.01 & 0.01 \\
\hline Aging & $2.04^{* * *}$ & $1.50^{* * *}$ & $2.94^{* * *}$ & $2.43^{* * *}$ & 0.21 & -0.22 & 0.42 & -1.57 & $3.75^{* *}$ & $4.91^{* * *}$ & $2.55^{* * *}$ & $1.92^{* * *}$ & $4.68^{* *}$ & $3.65^{*}$ & $2.22^{* * *}$ & $1.50^{* *}$ & $2.67^{* * *}$ & $2.22^{* * *}$ & $2.10^{* * *}$ & $1.84^{* * *}$ & $2.34^{* * *}$ & $1.91^{* * *}$ & $2.95 * * *$ & $2.34^{* * *}$ \\
\hline & 0.55 & 0.58 & 0.47 & 0.47 & 0.82 & 0.89 & 1.8 & 1.86 & 1.72 & 1.7 & 0.67 & 0.7 & 1.94 & 2.07 & 0.58 & 0.58 & 0.54 & 0.58 & 0.31 & 0.33 & 0.57 & 0.59 & 0.58 & 0.58 \\
\hline Lagged Growth & $-0.15^{*}$ & $-0.26 * *$ & $-0.44^{* * *}$ & $-0.55^{* * *}$ & $-0.38^{* * *}$ & $-0.41^{* * *}$ & $-0.21^{*}$ & $-0.36^{* * *}$ & 0 & -0.12 & $-0.38^{* *}$ & $-0.55^{* * *}$ & -0.12 & $-0.24^{*}$ & $-0.21^{* *}$ & $-0.35^{* * *}$ & -0.1 & $-0.21^{* * *}$ & $-0.11^{*}$ & $-0.20^{* * *}$ & $-0.15^{*}$ & $-0.26 * * *$ & -0.13 & $-0.25 * * *$ \\
\hline & 0.08 & 0.08 & 0.09 & 0.09 & 0.12 & 0.13 & 0.12 & 0.12 & 0.09 & 0.09 & 0.17 & 0.17 & 0.12 & 0.14 & 0.09 & 0.09 & 0.08 & 0.08 & 0.06 & 0.06 & 0.08 & 0.08 & 0.08 & 0.08 \\
\hline Energy & $0.15^{* * *}$ & $0.13^{* * *}$ & $0.17^{* * *}$ & $0.14^{* * *}$ & $0.24^{* * *}$ & $0.21 * * *$ & $0.16^{*}$ & 0.16 & $0.21^{* * *}$ & $0.19^{* * *}$ & $0.19^{* * *}$ & $0.17^{* * *}$ & $0.18^{* * *}$ & $0.16^{* * *}$ & $0.12^{* * *}$ & $0.09 * *$ & $0.18^{* * *}$ & $0.15^{* * *}$ & $0.14^{* * *}$ & $0.11^{* * *}$ & $0.11^{* * *}$ & $0.08^{* * *}$ & $0.17^{* * *}$ & $0.14^{* * *}$ \\
\hline & 0.03 & 0.03 & 0.02 & 0.03 & 0.03 & 0.03 & 0.09 & 0.1 & 0.02 & 0.03 & 0.03 & 0.03 & 0.03 & 0.03 & 0.03 & 0.03 & 0.03 & 0.03 & 0.02 & 0.02 & 0.03 & 0.03 & 0.02 & 0.03 \\
\hline Fiscal & $0.28^{* * *}$ & $0.23^{* * *}$ & $0.42^{* * *}$ & $0.38 * * *$ & 0.23 & 0.16 & -0.05 & -0.1 & $0.32^{* *}$ & $0.26^{*}$ & $0.21^{* * *}$ & $0.17^{* *}$ & $0.46^{* * *}$ & $0.37^{* * *}$ & $0.28^{* * *}$ & $0.25^{* * *}$ & $0.32^{* * *}$ & $0.28^{* * *}$ & $0.20^{* * *}$ & $0.17^{* * *}$ & $0.28^{* * *}$ & $0.24^{* * *}$ & $0.34^{* * *}$ & $0.28^{* * *}$ \\
\hline & 0.06 & 0.06 & 0.06 & 0.06 & 0.16 & 0.17 & 0.09 & 0.1 & 0.13 & 0.14 & 0.08 & 0.08 & 0.12 & 0.13 & 0.08 & 0.07 & 0.06 & 0.06 & 0.04 & 0.04 & 0.06 & 0.06 & 0.07 & 0.07 \\
\hline Net official flows (NOF) & $0.70^{* * *}$ & $0.78^{* * *}$ & $0.28^{*}$ & $0.37^{* *}$ & $0.63^{* *}$ & $0.78^{* *}$ & $1.12^{* * *}$ & $1.23^{* * *}$ & 0.26 & 0.45 & $0.50^{* * *}$ & $0.60^{* * *}$ & $0.59^{* * *}$ & $0.64^{* * *}$ & $0.71^{* * *}$ & $0.77^{* * *}$ & $0.49^{* * *}$ & $0.59 * * *$ & $0.60^{* * *}$ & $0.67^{* * *}$ & $0.66^{* * *}$ & $0.73^{* * *}$ & $0.35^{*}$ & $0.49 * * *$ \\
\hline & 0.16 & 0.18 & 0.15 & 0.16 & 0.3 & 0.31 & 0.28 & 0.3 & 0.26 & 0.29 & 0.17 & 0.18 & 0.21 & 0.23 & 0.15 & 0.16 & 0.16 & 0.18 & 0.12 & 0.13 & 0.18 & 0.18 & 0.18 & 0.19 \\
\hline Interaction with Mobility dummy & $-0.49 * * *$ & $-0.63^{* * *}$ & $-0.29^{* *}$ & $-0.43^{* * *}$ & $-0.54^{* *}$ & $-0.75^{* * *}$ & $-0.66^{* *}$ & $-0.84^{* *}$ & -0.19 & -0.33 & 0.11 & 0.05 & $-0.37^{* * *}$ & $-0.49^{* * *}$ & $-0.56^{* * *}$ & $-0.70^{* * *}$ & $-0.39^{* *}$ & $-0.55^{* * *}$ & $-0.35^{* *}$ & $-0.53^{* * *}$ & $-0.35^{*}$ & $-0.48^{* *}$ & -0.21 & $-0.39 * *$ \\
\hline & 0.17 & 0.19 & 0.13 & 0.15 & 0.23 & 0.24 & 0.31 & 0.35 & 0.39 & 0.42 & 0.41 & 0.45 & 0.14 & 0.16 & 0.14 & 0.15 & 0.15 & 0.17 & 0.17 & 0.19 & 0.18 & 0.19 & 0.18 & 0.19 \\
\hline Lagged stock of official assets (NOA) & 0 & -0.01 & $0.07^{* * *}$ & $0.07^{* * *}$ & -0.03 & $-0.04^{*}$ & $-0.04^{*}$ & $-0.04^{*}$ & 0.03 & 0 & 0 & -0.02 & $-0.07^{* * *}$ & $-0.06 * *$ & -0.01 & 0 & 0.02 & 0.01 & 0.01 & 0 & 0 & 0 & 0.04 & 0.03 \\
\hline & 0.02 & 0.02 & 0.02 & 0.02 & 0.02 & 0.02 & 0.02 & 0.02 & 0.04 & 0.04 & 0.04 & 0.04 & 0.02 & 0.02 & 0.03 & 0.03 & 0.02 & 0.02 & 0.02 & 0.02 & 0.02 & 0.02 & 0.02 & 0.02 \\
\hline Interaction with Mobility dummy & $0.07^{* * *}$ & $0.07^{* * *}$ & 0.01 & 0.02 & $0.10^{* * *}$ & $0.12^{* * *}$ & 0.04 & $0.06^{*}$ & 0.03 & 0.04 & 0.08 & 0.09 & $0.09 * *$ & $0.09^{* * *}$ & $0.07^{* * *}$ & $0.07^{* * *}$ & $0.04^{* *}$ & $0.06 * *$ & $0.03^{* *}$ & $0.05 * *$ & $0.06 * *$ & $0.06^{* * *}$ & 0.02 & 0.04 \\
\hline & 0.02 & 0.02 & 0.02 & 0.02 & 0.02 & 0.02 & 0.03 & 0.03 & 0.03 & 0.03 & 0.07 & 0.07 & 0.03 & 0.03 & 0.02 & 0.02 & 0.02 & 0.02 & 0.02 & 0.02 & 0.02 & 0.02 & 0.02 & 0.02 \\
\hline Mobility & 0 & 0 & $0.01 * *$ & $0.01^{* *}$ & 0.01 & 0.01 & 0 & 0 & -0.01 & 0 & 0 & 0 & 0 & 0 & 0 & 0 & 0 & 0 & $-0.01 * * *$ & $-0.01^{* * *}$ & 0 & 0 & $-0.03^{* * *}$ & $-0.02^{* * *}$ \\
\hline & 0 & 0 & 0 & 0 & 0.01 & 0.01 & 0.01 & 0.01 & 0.01 & 0.01 & 0 & 0 & 0 & 0 & 0 & 0 & 0 & 0 & 0 & 0 & 0.01 & 0.01 & 0.01 & 0.01 \\
\hline Nominal GDP, deviation from trend & $-0.04^{* * *}$ & $-0.04^{* * *}$ & & & & & & & & & & & & & & & & & & & & & & \\
\hline & 0.01 & 0.01 & & & & & & & & & & & & & & & & & & & & & & \\
\hline Flexible FX regime dummy & & & & & & & & & & & $-0.04^{* * *}$ & $-0.04 * * *$ & & & & & & & & & & & & \\
\hline & & & & & & & & & & & 0.01 & 0.01 & & & & & & & & & & & & \\
\hline interaction with NOF & & & & & & & & & & & $1.80^{* *}$ & $1.90^{* *}$ & & & & & & & & & & & & \\
\hline & & & & & & & & & & & 0.73 & 0.82 & & & & & & & & & & & & \\
\hline interaction with NOF interaction & & & & & & & & & & & $-2.21^{* * *}$ & $-2.48^{* * *}$ & & & & & & & & & & & & \\
\hline & & & & & & & & & & & 0.85 & 0.96 & & & & & & & & & & & & \\
\hline interaction with NOA & & & & & & & & & & & -0.2 & -0.15 & & & & & & & & & & & & \\
\hline & & & & & & & & & & & 0.14 & 0.15 & & & & & & & & & & & & \\
\hline interaction with NOA interaction & & & & & & & & & & & 0.18 & 0.15 & & & & & & & & & & & & \\
\hline & & & & & & & & & & & 0.16 & 0.17 & & & & & & & & & & & & \\
\hline Tot index & & & & & & & & & & & & & & & & & & & & & $0.02^{* *}$ & 0.02 & & \\
\hline & & & & & & & & & & & & & & & & & & & & & 0.01 & 0.01 & & \\
\hline $\begin{array}{l}\text { R-squared } \\
\end{array}$ & 0.58 & 0.46 & 0.72 & 0.59 & 0.51 & 0.40 & $\overline{0.72}$ & 0.60 & 0.58 & 0.46 & 0.34 & 0.13 & 0.60 & 0.51 & 0.56 & $\overline{0.43}$ & 0.59 & 0.46 & 0.55 & 0.45 & 0.58 & 0.47 & 0.60 & 0.48 \\
\hline Observations & 794 & 794 & 824 & 824 & 824 & 824 & 794 & 794 & 573 & 573 & 794 & 794 & 604 & 604 & 632 & 632 & 981 & 981 & 1124 & 1124 & 794 & 794 & 794 & 794 \\
\hline $\begin{array}{l}\text { Robust standard errors in parentheses } \\
\text { We add } 1 \text { to the estimated coefficients on } \\
{ }^{*} p<0.1,{ }^{* *} p<0.05,{ }^{* * *} p<0.01\end{array}$ & II NPFX re & gressions. & & & & & & & & & & & & & & & & & & & & & & \\
\hline Implied effect on CA under high mobility & 0.21 & 0.15 & -0.01 & -0.06 & 0.09 & 0.03 & 0.46 & 0.39 & 0.07 & 0.12 & 0.61 & 0.65 & 0.22 & 0.15 & 0.15 & 0.07 & 0.12 & 0.04 & 0.25 & 0.14 & 0.31 & 0.25 & 0.14 & 0.10 \\
\hline Implied effect on CA under low mobility & 0.70 & 0.78 & 0.28 & 0.37 & 0.63 & 0.78 & 1.12 & 1.21 & 0.26 & 0.45 & 0.50 & 0.60 & 0.59 & 0.64 & 0.71 & 0.77 & 0.51 & 0.59 & 0.60 & 0.67 & 0.66 & 0.73 & 0.35 & 0.49 \\
\hline
\end{tabular}




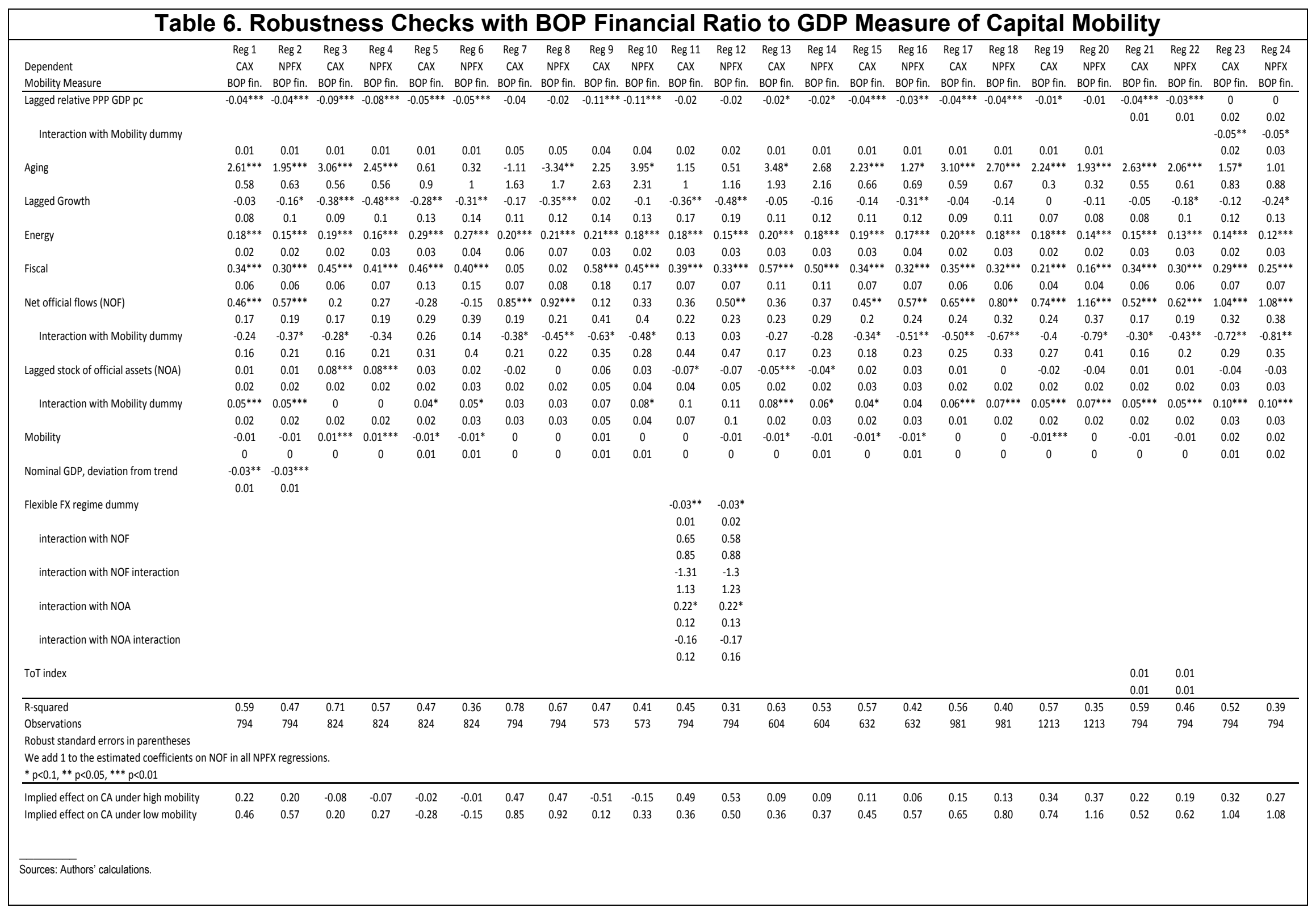




\begin{tabular}{|c|c|c|c|c|c|c|c|c|c|c|c|c|c|c|c|c|c|c|c|c|c|c|c|c|}
\hline & & Tab & ole 7. & . Rol & bust & thes & s Cr & neck & is W & ith & ${ }^{\mathrm{C}} \mathrm{A}$ & It $\mathbf{M}$ & easu & ure & of Ca & apita & al Mo & bilit & & & & & & \\
\hline & Reg 1 & Reg 2 & Reg 3 & $\operatorname{Reg} 4$ & $\operatorname{Reg} 5$ & Reg 6 & Reg 7 & Reg 8 & Reg 9 & $\operatorname{Reg} 10$ & $\operatorname{Reg} 11$ & $\operatorname{Reg} 12$ & $\operatorname{Reg} 13$ & Reg 14 & $\operatorname{Reg} 15$ & $\operatorname{Reg} 16$ & Reg 17 & Reg 18 & Reg 19 & $\operatorname{Reg} 20$ & $\operatorname{Reg} 21$ & $\operatorname{Reg} 22$ & $\operatorname{Reg} 23$ & $\operatorname{Reg} 24$ \\
\hline $\begin{array}{l}\text { Dependent } \\
\text { Mobility Measure }\end{array}$ & $\begin{array}{l}\text { CAX } \\
\text { PCalt }\end{array}$ & $\begin{array}{l}\text { NPFX } \\
\text { PCalt }\end{array}$ & $\begin{array}{l}\text { CAX } \\
\text { PCalt }\end{array}$ & $\begin{array}{l}\text { NPFX } \\
\text { PCalt }\end{array}$ & $\begin{array}{l}\text { CAX } \\
\text { PC alt }\end{array}$ & $\begin{array}{l}\text { NPFX } \\
\text { PCalt }\end{array}$ & $\begin{array}{l}\text { CAX } \\
\text { PCalt }\end{array}$ & $\begin{array}{l}\text { NPFX } \\
\text { PCalt }\end{array}$ & $\begin{array}{l}\text { CAX } \\
\text { PC alt }\end{array}$ & $\begin{array}{l}\text { NPFX } \\
\text { PCalt }\end{array}$ & $\begin{array}{l}\text { CAX } \\
\text { PCalt }\end{array}$ & $\begin{array}{l}\text { NPFX } \\
\text { PCalt }\end{array}$ & $\begin{array}{l}\text { CAX } \\
\text { PCalt }\end{array}$ & NPFX & CAX & NPFX & CAX & NPFX & CAX & $\begin{array}{l}\text { NPFX } \\
\text { PP }\end{array}$ & CAX & $\begin{array}{c}\text { NPFX } \\
\text { PC }\end{array}$ & CAX & NPFX \\
\hline \multirow{2}{*}{$\begin{array}{l}\text { Mobility Measure } \\
\text { Lagged relative PPP GDP pc }\end{array}$} & $-0.04^{* * *}$ & $-0.04^{* * *}$ & $-0.09^{* * *}$ & $\frac{P \text { dit }}{-0.09 * *}$ & $-0.02^{*}$ & $\frac{-0.02}{-0.02}$ & 0 & 0.02 & $\frac{1}{-0.077^{* *}}$ & $\frac{P C \text { at }}{-0.07^{* * *}}$ & $\frac{p l i l}{-0.02}$ & $\frac{P C \text { att }}{-0.02}$ & $\frac{-0.03^{* * *}}{-P x^{2}}$ & $\frac{P C \text { at }}{-0.03^{* *}}$ & $\frac{P \text { calt }}{-0.03^{* *}}$ & $\frac{-0.03^{* *}}{-0 .}$ & $\frac{\mathrm{PC} \text { at }}{-0.03^{* * *}}$ & $\frac{P c \text { att }}{-0.03^{* * *}}$ & $\frac{P C \text { at }}{-0.01}$ & $\frac{P C \text { att }}{-0.01}$ & $\frac{P C \text { att }}{-0.03^{* *}}$ & $\frac{-0.03^{* *}}{-0 .}$ & $\frac{P C \text { alt }}{-0.06 * *}$ & $\frac{-0.08^{* * *}}{-\frac{1}{2}}$ \\
\hline & 0.01 & 0.01 & 0.01 & 0.01 & 0.01 & 0.02 & 0.03 & 0.03 & 0.03 & 0.03 & 0.01 & 0.02 & 0.01 & 0.01 & 0.01 & 0.01 & 0.01 & 0.01 & 0.01 & 0.01 & 0.01 & 0.01 & 0.03 & 0.03 \\
\hline Interaction with Mobility dummy & & & & & & & & & & & & & & & & & & & & & & & 0.04 & 0.05 \\
\hline \multirow[t]{2}{*}{ Aging } & $2.67^{* * *}$ & $2.22^{* * *}$ & $2.32^{* * *}$ & $1.82^{* * *}$ & 0.21 & -0.22 & -0.71 & $-3.02 * *$ & 2.53 & $4.01^{* *}$ & $3.42^{* * *}$ & $2.79^{* * *}$ & $4.64^{* *}$ & $3.62^{*}$ & $2.74^{* * *}$ & $2.13^{* * *}$ & $3.30^{* * *}$ & $2.86^{* * *}$ & $2.76^{* * *}$ & $2.43^{* * *}$ & $2.59^{* * *}$ & $2.16^{* * *}$ & $\begin{array}{c}0.03 \\
3.02 * * *\end{array}$ & $\begin{array}{c}0.03 \\
2.65 * *\end{array}$ \\
\hline & 0.5 & 0.53 & 0.45 & 0.45 & 0.86 & 0.95 & 1.33 & 1.32 & 2 & 1.85 & 0.65 & 0.66 & 2.05 & 2.17 & 0.57 & 0.59 & 0.49 & 0.52 & 0.33 & 0.34 & 0.5 & 0.54 & 0.51 & 0.54 \\
\hline \multirow{2}{*}{ Lagged Growth } & -0.08 & $-0.19 * *$ & $-0.49 * * *$ & $-0.59 * * *$ & $-0.29 * *$ & $-0.32 * *$ & $-0.20^{*}$ & $-0.38^{* * *}$ & 0.04 & -0.09 & -0.13 & $-0.27^{*}$ & -0.12 & $-0.22^{*}$ & $-0.16^{*}$ & $-0.32^{* * *}$ & -0.06 & $-0.18^{* *}$ & -0.06 & $-0.13^{*}$ & $-0.13^{*}$ & $-0.25^{* * *}$ & -0.11 & $-0.23 * * *$ \\
\hline & 0.07 & 0.08 & 0.08 & 0.08 & 0.13 & 0.14 & 0.11 & 0.1 & 0.09 & 0.09 & 0.15 & 0.15 & 0.12 & 0.13 & 0.09 & 0.08 & 0.07 & 0.07 & 0.07 & 0.07 & 0.07 & 0.08 & 0.08 & 0.08 \\
\hline Energy & $\begin{array}{c}0.18^{* * *} \\
0.02\end{array}$ & $\begin{array}{c}0.16^{* * *} \\
0.02\end{array}$ & $\begin{array}{l}0.17^{* * *} \\
0.02\end{array}$ & $\begin{array}{c}0.15 * * * \\
0.02\end{array}$ & $\begin{array}{l}0.25 * * * \\
0.03\end{array}$ & $\begin{array}{l}0.22^{* * *} \\
0.03\end{array}$ & $\begin{array}{l}0.24^{* * *} \\
0.05\end{array}$ & $\begin{array}{c}0.25^{* * *} \\
0.06\end{array}$ & $\begin{array}{c}0.22^{* * *} \\
0.03\end{array}$ & $\begin{array}{c}0.20 * * * \\
0.02\end{array}$ & $\begin{array}{c}0.18^{* * *} \\
0.03\end{array}$ & $\begin{array}{l}0.15^{* * *} \\
0.03\end{array}$ & $\begin{array}{c}0.20^{* * *} \\
0.03\end{array}$ & $\begin{array}{c}0.18^{* * *} \\
0.03\end{array}$ & $\begin{array}{l}0.18 * * * \\
0.03\end{array}$ & $\begin{array}{c}0.16^{* * *} \\
0.03\end{array}$ & $\begin{array}{l}0.20^{* * *} \\
0.02\end{array}$ & $\begin{array}{c}0.17^{* * *} \\
0.02\end{array}$ & $\begin{array}{c}0.16^{* * *} \\
0.02\end{array}$ & $\begin{array}{c}0.14^{* * *} \\
0.02\end{array}$ & $\begin{array}{c}0.14^{* * *} \\
0.02\end{array}$ & $\begin{array}{c}0.11^{* * *} \\
0.02\end{array}$ & $\begin{array}{c}0.18^{* * *} \\
0.02\end{array}$ & $\begin{array}{c}0.16^{* * *} \\
0.02\end{array}$ \\
\hline \multirow[t]{2}{*}{ Fiscal } & $\begin{array}{l}0.32^{* * *} \\
0.06\end{array}$ & $0.28^{* * *}$ & $\begin{array}{l}0.40^{* * *} \\
0.05\end{array}$ & $0.37^{* * *}$ & $0.33^{* *}$ & 0.27 & 0.05 & 0.03 & $0.49^{* * *}$ & $0.37^{* * *}$ & $0.38^{* * * *}$ & $0.31^{* * *}$ & $0.47^{* * *}$ & $0.40^{* * * *}$ & $0.32^{* * *}$ & $0.30^{* * * *}$ & $0.38^{* * *}$ & $0.34^{* * * *}$ & $0.27 * * *$ & $0.23^{* * *}$ & $0.29 * * *$ & $0.25 * * *$ & $0.36^{* * *}$ & $0.34^{* * * *}$ \\
\hline & 0.06 & 0.06 & 0.05 & 0.06 & 0.16 & 0.18 & 0.07 & 0.07 & 0.14 & 0.13 & 0.08 & 0.08 & 0.11 & 0.11 & 0.08 & 0.07 & 0.06 & 0.06 & 0.05 & 0.05 & 0.06 & 0.06 & 0.07 & 0.07 \\
\hline \multirow[t]{2}{*}{ Net official flows (NOF) } & $0.43^{* * *}$ & $0.48^{* * *}$ & $0.38^{* * *}$ & $0.44^{* * *}$ & 0.48 & $0.62^{*}$ & $0.91^{* * *}$ & $0.90^{* * *}$ & 0.03 & 0.28 & $0.28^{*}$ & $0.40^{* *}$ & $0.56 * * *$ & $0.60^{* * *}$ & $0.54^{* * *}$ & $0.60^{* * *}$ & $0.25 *$ & $0.39 * *$ & $0.29 * *$ & $0.32^{* *}$ & $0.56^{* * *}$ & $0.62^{* * *}$ & $0.31^{*}$ & $0.32^{*}$ \\
\hline & 0.12 & 0.13 & 0.12 & 0.13 & 0.32 & 0.33 & 0.14 & 0.15 & 0.25 & 0.24 & 0.17 & 0.17 & 0.15 & 0.17 & 0.13 & 0.14 & 0.14 & 0.16 & 0.13 & 0.15 & 0.12 & 0.13 & 0.17 & 0.19 \\
\hline \multirow[t]{2}{*}{ Interaction with Mobility dummy } & -0.17 & $-0.26^{*}$ & $-0.31^{* * *}$ & $-0.41^{* * *}$ & $-0.58^{* *}$ & $-0.77^{* * *}$ & $-0.63 * * *$ & $-0.67^{* * *}$ & $-0.36^{*}$ & -0.29 & -0.28 & -0.29 & -0.24 & $-0.31^{*}$ & $-0.39^{* * *}$ & $-0.52^{* * *}$ & -0.1 & -0.25 & 0.01 & -0.09 & $-0.27^{* *}$ & $-0.36 * *$ & -0.12 & -0.19 \\
\hline & 0.12 & 0.15 & 0.12 & 0.14 & 0.26 & 0.28 & 0.16 & 0.18 & 0.21 & 0.18 & 0.19 & 0.19 & 0.15 & 0.17 & 0.11 & 0.14 & 0.14 & 0.16 & 0.13 & 0.16 & 0.13 & 0.15 & 0.14 & 0.17 \\
\hline \multirow[t]{2}{*}{ Lagged stock of official assets (NOA) } & 0.02 & 0.03 & $0.07 * * *$ & $0.07 * * *$ & -0.02 & -0.03 & $-0.03 * *$ & -0.02 & 0.06 & 0.03 & 0.06 & 0.05 & $-0.07 * * *$ & $-0.06 * * *$ & 0.02 & 0.03 & $0.05^{* * *}$ & $0.04^{* *}$ & $0.04^{*}$ & $0.04^{*}$ & 0.01 & 0.02 & 0.04 & $0.05^{*}$ \\
\hline & 0.02 & 0.02 & 0.02 & 0.02 & 0.03 & 0.03 & 0.02 & 0.02 & 0.04 & 0.04 & 0.04 & 0.04 & 0.02 & 0.02 & 0.03 & 0.03 & 0.02 & 0.02 & 0.02 & 0.02 & 0.02 & 0.02 & 0.03 & 0.03 \\
\hline \multirow{2}{*}{ Interaction with Mobility dummy } & $0.03^{*}$ & $0.04^{*}$ & 0.01 & 0.01 & $0.09^{* * *}$ & $0.11^{* * *}$ & $0.05 * *$ & $0.04^{*}$ & 0 & 0.01 & -0.06 & -0.05 & $0.06^{* *}$ & 0.06 & $0.04^{*}$ & 0.03 & 0.01 & 0.02 & 0 & 0 & $0.04^{* *}$ & $0.04 * *$ & 0.02 & 0.01 \\
\hline & 0.02 & 0.02 & 0.02 & 0.02 & 0.03 & 0.03 & 0.02 & 0.02 & 0.03 & 0.03 & 0.06 & 0.05 & 0.03 & 0.03 & 0.03 & 0.03 & 0.02 & 0.02 & 0.02 & 0.02 & 0.02 & 0.02 & 0.03 & 0.03 \\
\hline \multirow[t]{2}{*}{ Mobility } & $-0.01 * *$ & $-0.01 * *$ & $0.01^{* *}$ & $0.01^{* *}$ & -0.01 & -0.01 & $-0.01^{*}$ & $-0.01^{*}$ & $-0.01^{*}$ & -0.01 & $-0.02^{* *}$ & $-0.01^{*}$ & 0 & 0 & $-0.01^{* *}$ & $-0.01^{*}$ & $-0.02^{* * *}$ & $-0.02^{* * *}$ & $-0.02 * * *$ & $-0.02 * * *$ & $-0.01 * *$ & $-0.01^{*}$ & $-0.02 * *$ & $-0.02^{* *}$ \\
\hline & 0.01 & 0.01 & 0.01 & 0.01 & 0.01 & 0.01 & 0.01 & 0.01 & 0.01 & 0.01 & 0.01 & 0.01 & 0.01 & 0.01 & 0.01 & 0.01 & 0.01 & 0.01 & 0.01 & 0.01 & 0.01 & 0.01 & 0.01 & 0.01 \\
\hline Nominal GDP, deviation from trend & $-0.04 * * *$ & $\begin{array}{c}-0.04 * * * \\
0.01\end{array}$ & & & & & & & & & & & & & & & & & & & & & & \\
\hline \multirow[t]{2}{*}{ Flexible FX regime dummy } & & & & & & & & & & & $-0.02^{*}$ & $-0.02^{*}$ & & & & & & & & & & & & \\
\hline & & & & & & & & & & & 0.01 & 0.01 & & & & & & & & & & & & \\
\hline \multirow[t]{2}{*}{ interaction with NOF } & & & & & & & & & & & 0.16 & 0.32 & & & & & & & & & & & & \\
\hline & & & & & & & & & & & 0.6 & 0.64 & & & & & & & & & & & & \\
\hline \multirow[t]{2}{*}{ interaction with NOF interaction } & & & & & & & & & & & 0.08 & -0.23 & & & & & & & & & & & & \\
\hline & & & & & & & & & & & 0.68 & 0.7 & & & & & & & & & & & & \\
\hline \multirow{2}{*}{ interaction with NOA } & & & & & & & & & & & -0.1 & -0.11 & & & & & & & & & & & & \\
\hline & & & & & & & & & & & 0.14 & 0.13 & & & & & & & & & & & & \\
\hline \multirow{2}{*}{ ToT index } & & & & & & & & & & & & & & & & & & & & & & & & \\
\hline & & & & & & & & & & & 0.14 & 0.13 & & & & & & & & & $\begin{array}{l}0.03 * * * \\
0.01\end{array}$ & $\begin{array}{c}0.02^{* *} \\
0.01\end{array}$ & & \\
\hline R-squared & 0.60 & 0.48 & 0.73 & 0.60 & 0.51 & 0.36 & 0.81 & 0.72 & 0.57 & 0.45 & 0.14 & 0.135 & 0.61 & 0.51 & 0.59 & 0.45 & 0.61 & 0.47 & 0.54 & 0.42 & 0.01 & 0.01 & 0.60 & 0.47 \\
\hline Observations & 794 & 794 & 828 & 828 & 828 & 828 & 798 & 798 & 575 & 575 & 798 & 798 & 606 & 606 & 636 & 636 & 986 & 986 & 1094 & 1094 & 794 & 794 & 794 & 794 \\
\hline $\begin{array}{l}\text { Robust standard errors in parentheses } \\
\text { We add } 1 \text { to the estimated coefficients on } \\
* \mathrm{p}<0.1, * * \mathrm{p}<0.05, * * * \mathrm{p}<0.01\end{array}$ & in all NPFX & Ex rere & & & & & & & & & & & & & & & & & & & & & & \\
\hline Implied effect on CA under high mobility & 0.26 & 0.22 & 0.07 & 0.03 & -0.10 & -0.15 & 0.28 & 0.23 & -0.33 & -0.01 & 0.00 & 0.11 & 0.32 & 0.29 & 0.15 & 0.08 & 0.15 & 0.14 & 0.30 & 0.23 & 0.29 & 0.26 & 0.19 & 0.13 \\
\hline Implied effect on CA under low mobility & 0.43 & 0.48 & 0.38 & 0.44 & 0.48 & 0.62 & 0.91 & 0.90 & 0.03 & 0.28 & 0.28 & 0.40 & 0.56 & 0.60 & 0.54 & 0.60 & 0.25 & 0.39 & 0.29 & 0.32 & 0.56 & 0.62 & 0.31 & 0.32 \\
\hline Sources: Authors' calculations. & & & & & & & & & & & & & & & & & & & & & & & & \\
\hline
\end{tabular}




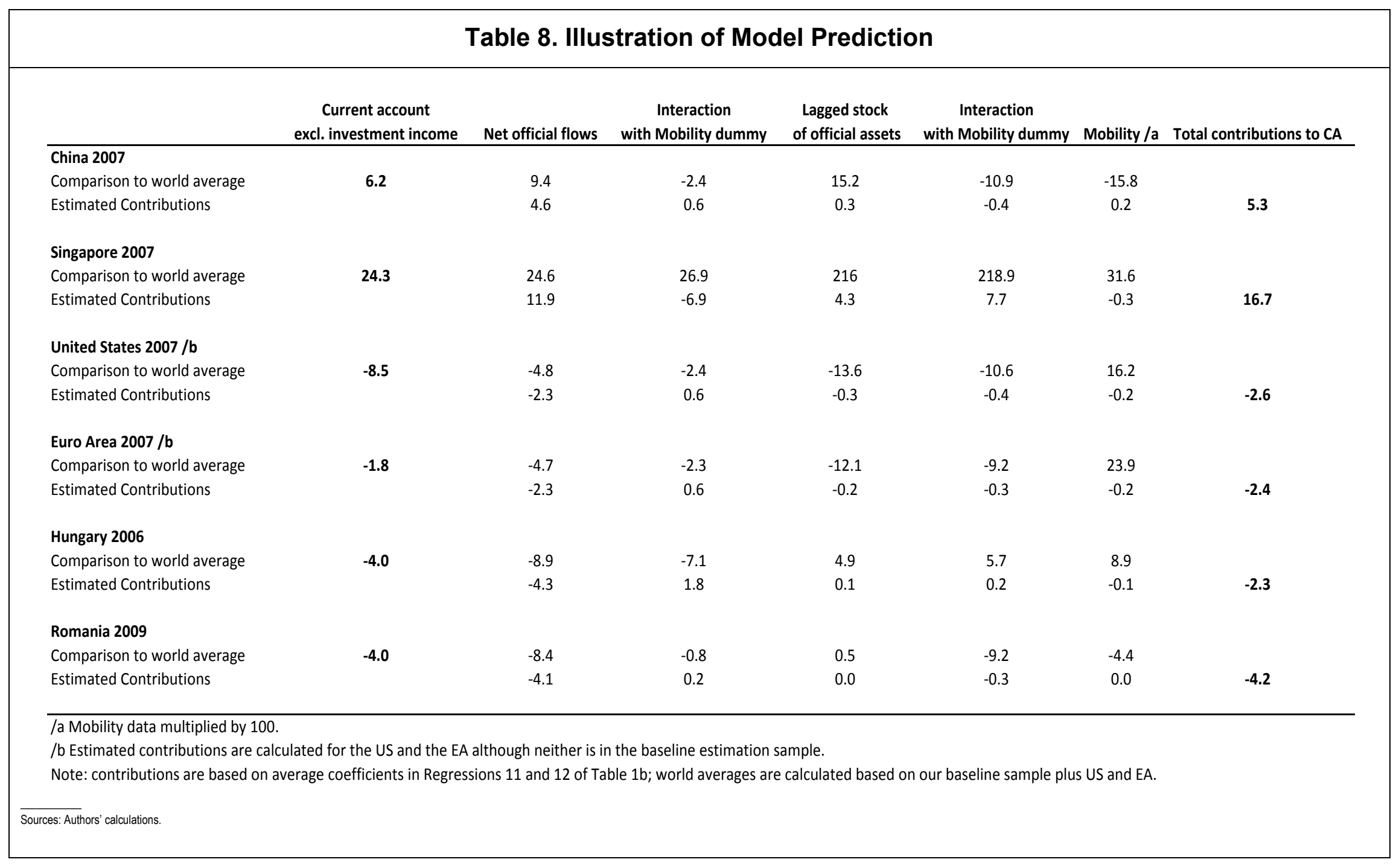


Figure 1. Net Official Financial Flows (USD billions)

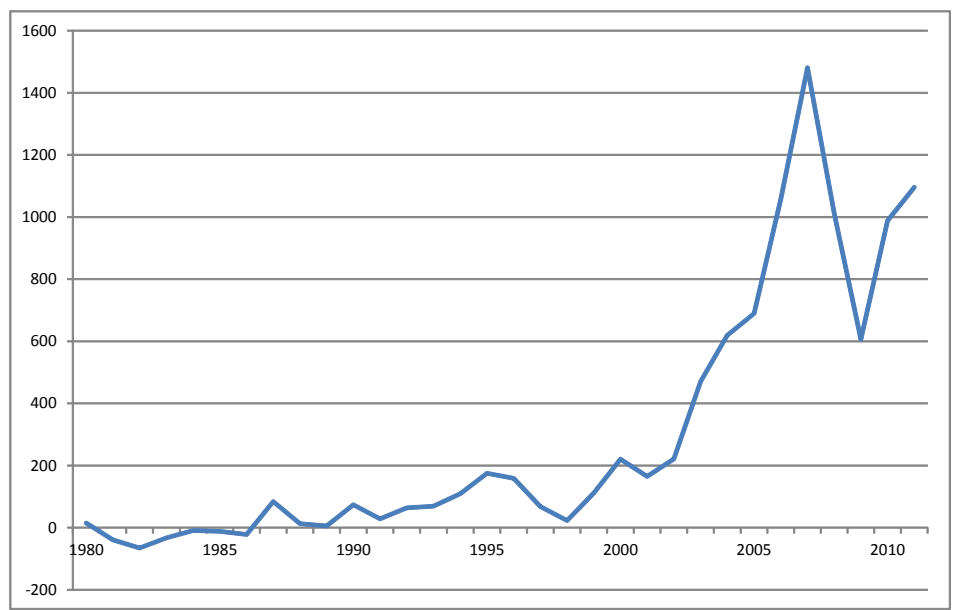

Note: Excludes countries with large unreported sovereign wealth funds. Sources: IMF Balance of Payments, Norges Bank, and authors' calculations.

\section{Figure 2. Net External Accounts of Countries with Current Account Surpluses (percent of world GDP)}

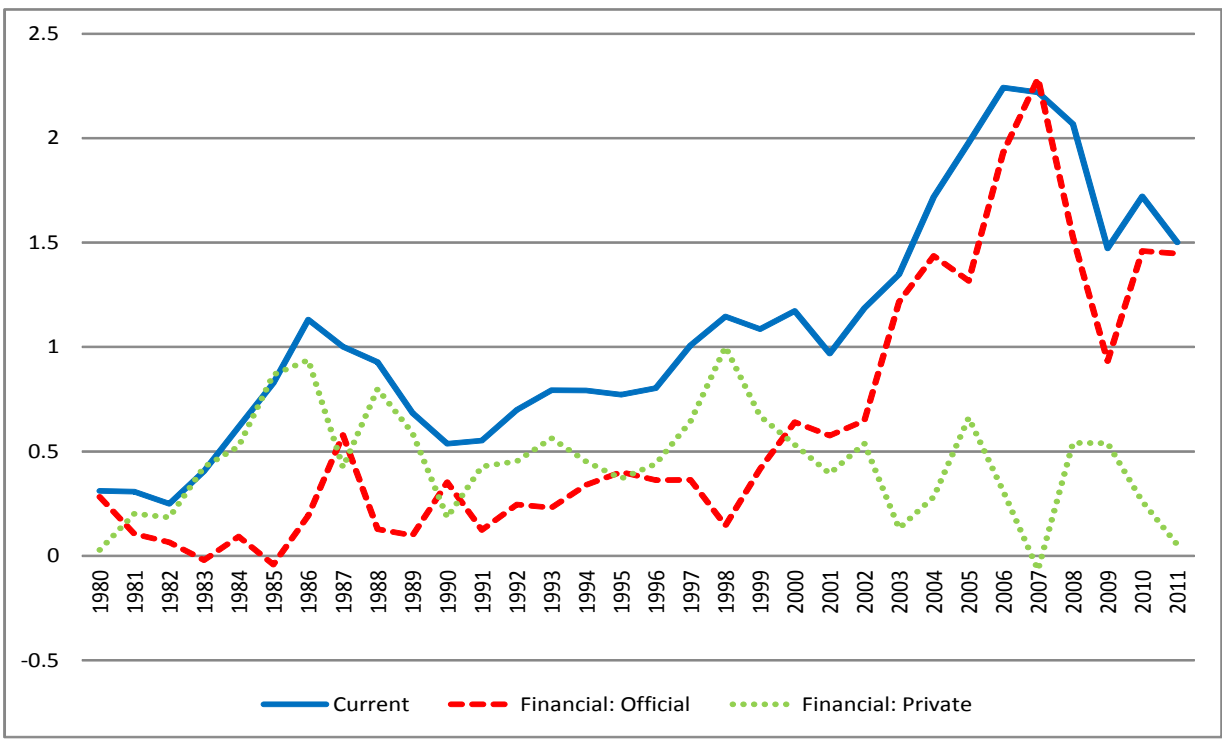

Note: Excludes countries with large unreported sovereign wealth funds. Sources: IMF Balance of Payments, Norges Bank, and authors' calculations. 
Figure 3. Median Values of Capital Control (Inverted)

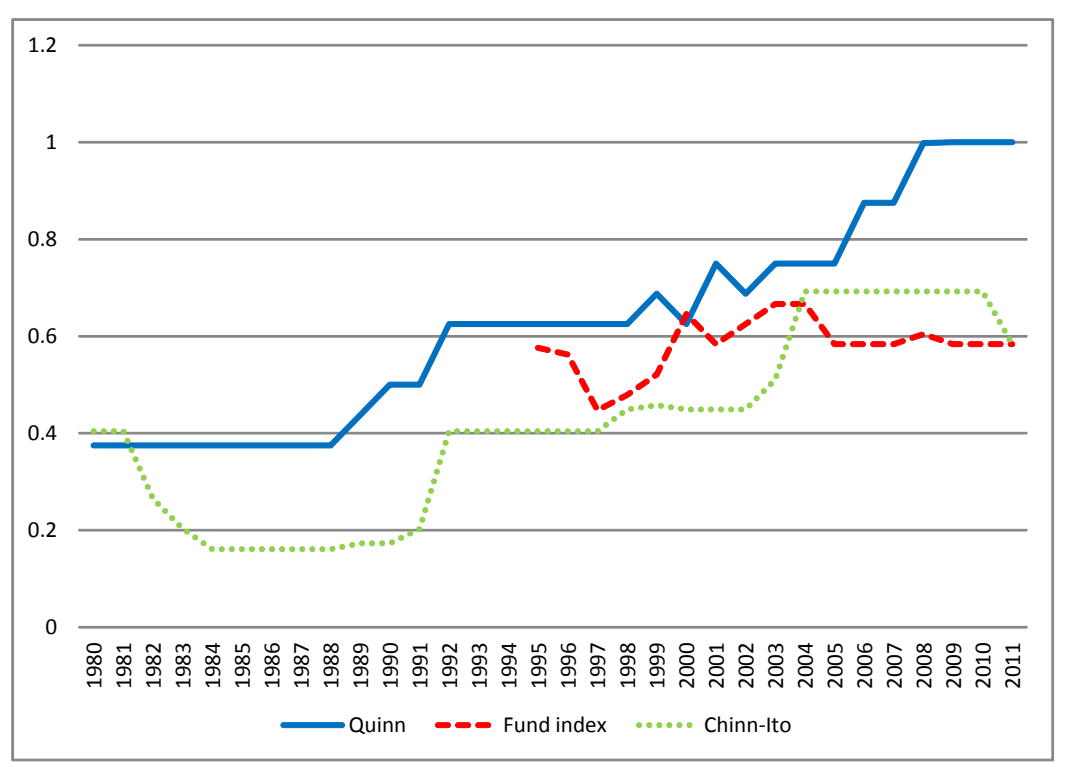

Source: International Monetary Fund. Excludes low-income countries.

Figure 4. Median Values of Institutional Quality Measures

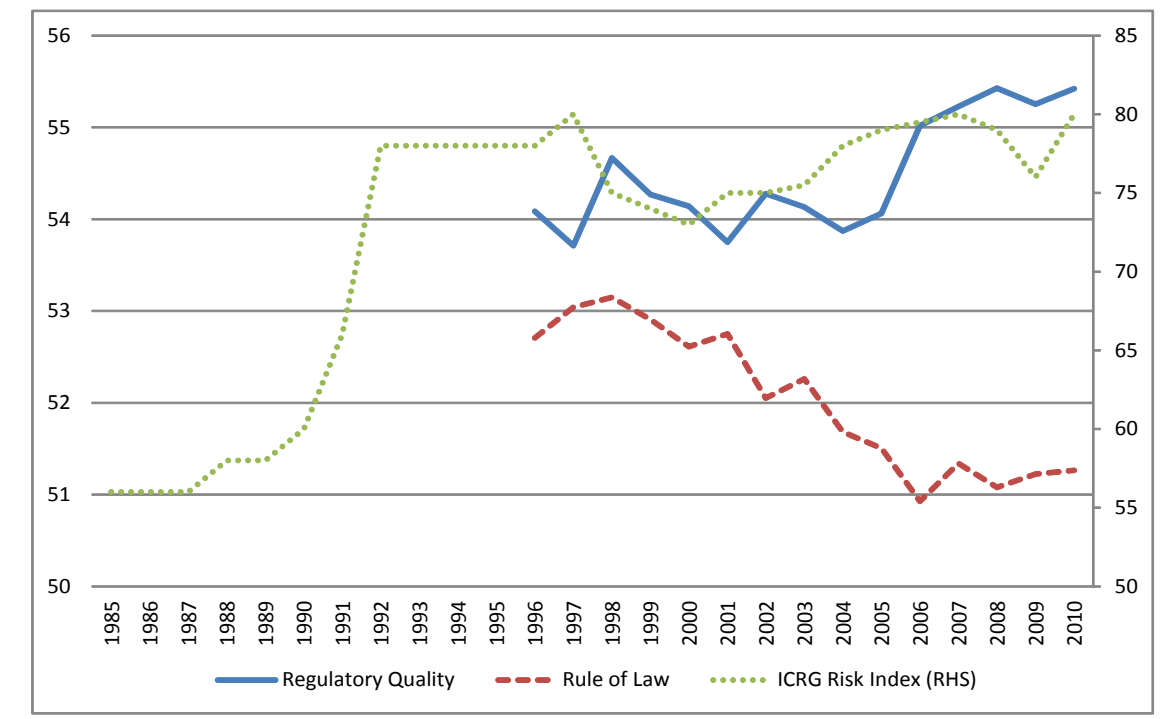

Source: International Monetary Fund. Excludes low-income countries. 
Figure 5. Median Values of Financial Market Measures

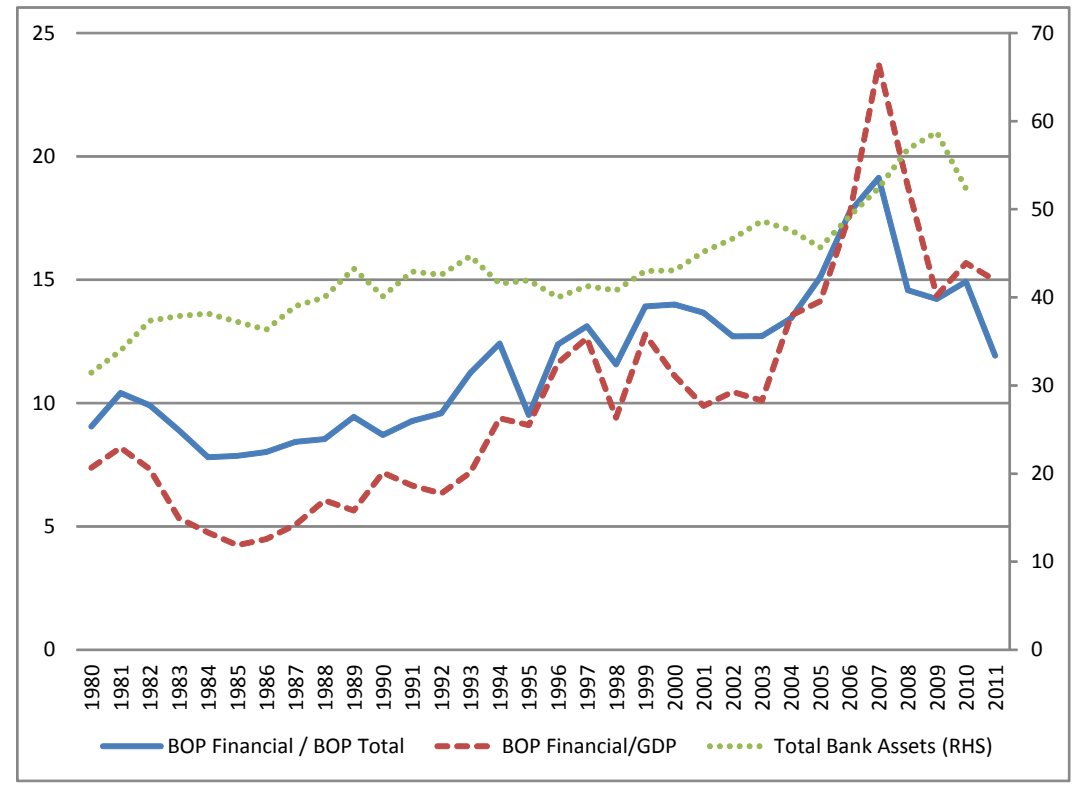

Source: International Monetary Fund. Excludes low-income countries.

Figure 6. Coefficients on Net Official Flows Term under Low and High Mobility

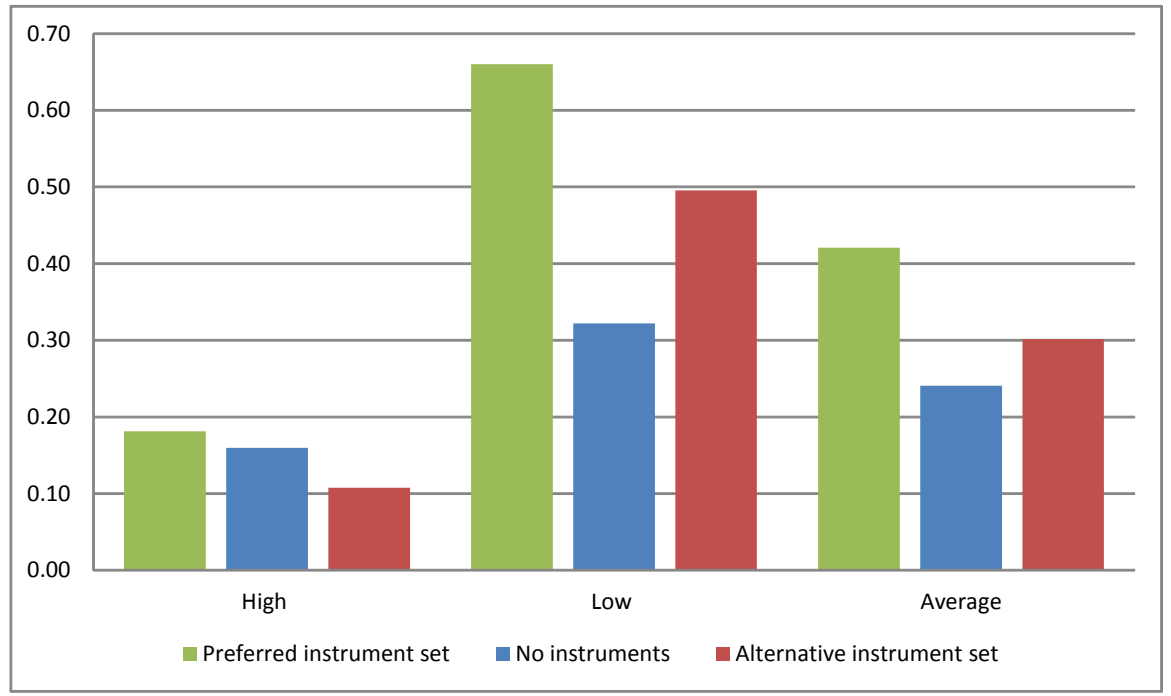

Source: Authors' calculations.

CInternational Monetary Fund. Not for Redistribution 


\section{APPENDiX: Data Sources AND Definitions}

Baseline sample (Table 2): Albania, Algeria, Argentina, Australia, Azerbaijan, Belarus, Botswana, Brazil, Bulgaria, Canada, Chile, China, Colombia, Costa Rica, Croatia, Cyprus, Czech Republic, Denmark, Dominican Republic, Ecuador, Egypt, El Salvador, Estonia, Gabon, Guatemala, Hong Kong SAR, Hungary, Iceland, India, Indonesia, Israel, Jamaica, Japan, Jordan, Kazakhstan, Korea, Latvia, Lebanon, Libya, Lithuania, Malaysia, Malta, Mexico, Morocco, New Zealand, Norway, Pakistan, Panama, Paraguay, Peru, Philippines, Poland, Romania, Russia, Saudi Arabia, Singapore, Slovak Republic, Slovenia, South Africa, Sri Lanka, Suriname, Sweden, Switzerland, Syria, Thailand, The Bahamas, Tunisia, Turkey, Ukraine, United Kingdom, Uruguay, Venezuela.

Sources: IMF, Balance of Payments Statistics (BOP); IMF, International Financial Statistics (IFS); IMF, World Economic Outlook (WEO); The PRS Group International Country Risk Guide (ICRG); United Nations, World Population Prospects 2010 (UN); World Bank, World Development Indicators (WDI); World Bank, Worldwide Governance Indicators (WGI); Norway, Norges Bank; and Singapore, Ministry of Finance. Updated data on capital controls based on Quinn (1997), Chinn and Ito (2006), and Fund (2009) were obtained from staff at the IMF.

CAX: The BOP current account balance minus BOP net investment income.

NOF: From the BOP data, NOF is the sum of reserves flows and net portfolio investment and other investment flows for central bank and general government except that portfolio and other liability flows are set at zero for advanced economies because they do not borrow significantly in foreign currency. For Norway we add flows by the Government Pension Fund Global based on data from Norges Bank because Norway does not include these flows in general government flows. We exclude from the sample all other countries that are known to have significant sovereign wealth funds (SWFs) whose flows are not reported in BOP official sectors (Bahrain, Brunei, Iran, Kuwait, Oman, Qatar, Saudi Arabia (before 2005), Trinidad and Tobago, and United Arab Emirates). For the United States and Mexico, we subtract the Federal Reserve swap flows in 2007-11..$^{40}$ These dollar swaps represent matched purchases and forward sales of dollars and thus do not create any net change in currency positions of the official sector.

NPFX: BOP net financial account flows minus BOP net investment income minus NOF.

NOA: IFS foreign exchange reserves minus WDI external public sector debt. Missing values of external public debt (mainly for advanced economies with little or no foreign-currency public debt) are set to zero. For Australia, NOA is adjusted for derivatives positions using data published by the Reserve Bank of Australia. For China, we add in some other official-sector

\footnotetext{
40 The remaining recipients of these swap flows are all advanced economies, and their official other liabilities flows are set to zero in any case. For the United States, swap flows show up in the other central bank assets flows.
} 
assets following the suggestions of Setser and Pandey (2009), but the additions are small relative to the reported reserves. For Norway we add in assets of the SWF as reported by Norges Bank. For Singapore, we substitute year-end 2009 NOA with financial assets of the government of Singapore as of March 2010 from the Ministry of Finance. We use the perpetual inventory method to calculate NOA for other years based on NOF.

GDP: Nominal GDP in US dollars and in local currency, and real GDP are from WEO.

MOBILITY: Measures of capital mobility are based on the following data.

Chinn-Ito: Capital controls index based on Chinn and Ito (2006), updated, from IMF staff.

Fund index: Fund staff's narrow de jure restrictiveness index based on Schindler (2009) but using some limited judgment, from IMF staff. The index was used in the studies underpinning the IMF's new institutional view on capital controls: http://www.imf.org/external/pubs/ft/survey/so/2012/POL120312A.htm.

Quinn: Capital controls index based on Quinn (1997), updated, from IMF staff.

> Financial Risk Index: ICRG

$>$ Rule of Law Index: WGI

$>$ Regulatory Quality Index: WGI

$>$ BOP Financial Share: BOP

$>$ BOP Financial/GDP Ratio: BOP and WEO

$>$ Bank Assets/GDP Ratio: WDI

Relative PPP GDP Per Capita: WEO (relative to US level). We set this as missing before 1996 for European transition economies.

Aging: 10-year forward change in ratio of elderly to working age population. Historical elderly ratios through 2010 are from WDI. Ratios for 2015 and 2020 are from UN and are interpolated and extrapolated in order to create 10-year changes for 2001-11.

Growth: 5-year moving average of growth rate of real GDP based on WEO. We corrected an error in Malta real GDP using IFS data. We set real GDP growth as missing for European transition economies before 1996.

Energy: Difference between energy production and consumption in tons of oil equivalent (WDI), converted into dollars using Brent oil price (IFS) assuming 7.33 barrels per ton and divided by nominal GDP (WEO).

Fiscal: General government balance in percent of GDP (WEO) is cyclically adjusted as the residual in a panel regression of the fiscal balance on the GDP gap with no country or year effects. The GDP gap is the difference between log real GDP and its 11-year centered moving 
average using WEO forecasts for 2013-16. A missing value for South Africa in 2005 is interpolated.

Scaling by trend GDP: When scaling data by GDP, we use the 11-year centered moving average of nominal GDP in US dollars (WEO), including forecast data through 2016.

Treatment of euro area: The 11 original members of the euro area (Austria, Belgium, Finland, France, Germany, Ireland, Italy, Luxembourg, Netherlands, Portugal, and Spain) plus Greece are treated as a single country by adding up data or creating nominal GDP-weighted averages where appropriate. The exception is euro-area foreign exchange reserves, which are taken from IFS for the euro area with additions for Greece in 1999 and 2000 and subtractions for the late joiners in years after they joined. Before 1999, euro-area reserves are calculated as 74 percent of the sum of individual members' reserves (based on the downward adjustment in January 1999) to exclude reserves in each others' currencies. Late joiners are treated as separate countries throughout. 


\section{REFERENCES}

Aizenman, Joshua (2006) International Reserves Management and the Current Account. NBER Working Paper No. 12734. Cambridge, MA: National Bureau of Economic Research.

, Yothin Jinjarak, and Nancy Marion (2013) China's Growth, Stability, and Use of International Reserves. NBER Working Paper No. 19739. Cambridge, MA: National Bureau of Economic Research.

Bayoumi, Tamim, and Christian Saborowski (2014) Accounting for Reserves. Journal of International Money and Finance 41: pp.1-29.

Branson, William and Dale Henderson (1985) The Specification and Influence of Asset Markets. In Ronald Jones and Peter Kenen (eds.), Handbook of International Economics, edition 1, volume 2, chapter 15, pp.749-805. Amsterdam: Elsevier.

Chinn, Menzie, and Hiro Ito (2006) What Matters for Financial Development? Capital Controls, Institutions, and Interactions. Journal of Development Economics 81, no. 1: pp.163-92.

, and (2008) Global Current Account Imbalances: American Fiscal Policy versus East Asian Savings. Review of International Economics 16, no. 3: pp.47998.

, and Eswar Prasad (2003) Medium-Term Determinants of Current Accounts in Industrial and Developing Countries: An Empirical Exploration. Journal of International Economics 59: pp. 47-76.

Gagnon, Joseph (2012) Global Imbalances and Foreign Asset Expansion by DevelopingEconomy Central Banks. Working Paper No. 12-5. Washington: Peterson Institute for International Economics.

, (2013) The Elephant Hiding in the Room: Currency Intervention and Trade Imbalances. Working Paper No.13-2. Washington: Peterson Institute for International Economics.

Ghosh, Atish, Jonathan Ostry, and Charalambos Tsangarides (2012) Shifting Motives: Explaining the Buildup in Official Reserves in Emerging Markets since the 1980s. Working Paper No. 12-34. Washington: International Monetary Fund.

Ilzetzki, Ethan, Carmen Reinhart, and Kenneth Rogoff (2008) The Country Chronologies and Background Material to Exchange Rate Arrangements in the 21st Century: Which Anchor Will Hold? Available at http://personal.lse.ac.uk/ilzetzki/IRRBack.htm. 
International Monetary Fund (IMF) (2012) External Balance Assessment (EBA): Technical Background of the Pilot Methodology. Washington: International Monetary Fund.

(2013) External Balance Assessment (EBA): Technical Background of the Pilot Methodology. Washington: International Monetary Fund.

Lee, Jaewoo, Gian Maria Milesi-Ferretti, Jonathan Ostry, Alessandro Prati, and Luca Ricci. (2008) Exchange Rate Assessments: CGER Methodologies. IMF Occasional Paper 261. Washington: International Monetary Fund.

Quinn, Dennis (1997) The Correlates of Change in International Financial Regulation. American Political Science Review 91: pp. 531-51.

Reinhart, Dennis, Luca Ricci, and Thierry Tressel (2010) International Capital Flows and Development: Financial Openness Matters. Working Paper No.10-235. Washington: International Monetary Fund.

Schindler, Martin (2009) Measuring Financial Integration: A New Data Set. International Monetary Fund Staff Papers 56, no.1: pp. 222-38.

Setser, Bradley, and Arpana Pandey (2009) China's \$1.5 Trillion Bet: Understanding China’s External Portfolio. CGS Working Paper (May update). New York: Council on Foreign Relations. 